\title{
Life-Cycle Energy Use and Greenhouse Gas Emissions Analysis for Bio-Liquid Jet Fuel from Open Pond-Based Micro-Algae under China Conditions
}

\author{
Xunmin Ou ${ }^{1,2, *}$, Xiaoyu Yan ${ }^{3}$, Xu Zhang ${ }^{1,2}$ and Xiliang Zhang ${ }^{1,2}$ \\ 1 Institute of Energy, Environment and Economy, Tsinghua University, Beijing 100084, China; \\ E-Mails: zhang-xu13@mails.tsinghua.edu.cn (X.Z.); zhang_xl@mail.tsinghua.edu.cn (X.Z.) \\ 2 China Automotive Energy Research Center, Tsinghua University, Beijing 100084, China \\ 3 Environment and Sustainability Institute, University of Exeter Penryn Campus, Penryn, \\ Cornwall TR10 9EZ, UK; E-Mail: xiaoyu.yan@exeter.ac.uk
}

* Author to whom correspondence should be addressed; E-Mail: ouxm@mail.tsinghua.edu.cn; Tel.: +86-10-6279-7376; Fax: +86-10-6279-6166.

Received: 29 July 2013; in revised form: 19 August 2013 / Accepted: 12 September 2013 / Published: 23 September 2013

\begin{abstract}
A life-cycle analysis (LCA) of greenhouse gas (GHG) emissions and energy use was performed to study bio-jet fuel (BJF) production from micro-algae grown in open ponds under Chinese conditions using the Tsinghua University LCA Model (TLCAM). Attention was paid to energy recovery through biogas production and cogeneration of heat and power (CHP) from the residual biomass after oil extraction, including fugitive methane $\left(\mathrm{CH}_{4}\right)$ emissions during the production of biogas and nitrous oxide $\left(\mathrm{N}_{2} \mathrm{O}\right)$ emissions during the use of digestate (solid residue from anaerobic digestion) as agricultural fertilizer. Analyses were performed based on examination of process parameters, mass balance conditions, material requirement, energy consumptions and the realities of energy supply and transport in China (i.e., electricity generation and heat supply primarily based on coal, multiple transport modes). Our LCA result of the BJF pathway showed that, compared with the traditional petrochemical pathway, this new pathway will increase the overall fossil energy use and carbon emission by $39 \%$ and $70 \%$, respectively, while decrease petroleum consumption by about $84 \%$, based on the same units of energy service. Moreover, the energy conservation and emission reduction benefit of this new pathway may be accomplished by two sets of approaches: wider adoption of low-carbon process fuels and optimization of algae cultivation and harvest, and oil extraction processes.
\end{abstract}


Keywords: life-cycle analysis; bio-liquid fuel; algae; China

\section{Introduction}

\subsection{China is Facing Rapidly Increasing Energy Demand and Oil Imports}

With global primary energy demand expected to grow at a compound annual growth rate of $1.6 \%$ from 2009 to 2035 driven by future global population and economic growth [1], mitigation of greenhouse gas (GHG) emissions is imperative. China's energy consumption has expanded quickly by $5.82 \%$ annually, underpinning the $10 \%$ average annual growth of the national economy during the 1981-2011 period [2]. Currently, China is the largest energy producer and consumer in the World [2]. In 2011, China consumed 1839 million tons of oil equivalents (Mtoe) of coal, 461.8 Mtoe of oil and 117.6 Mtoe of natural gas (NG), representing 49.4\%, $11.4 \%$ and $4.0 \%$ of the World total, respectively [3].

China is also facing energy supply problems due to limited fossil energy resources. Its per capita reserves of coal, petroleum and NG are $67.0 \%, 5.4 \%$, and $7.5 \%$ of World averages, respectively [4]. China's dependence on foreign energy sources has been increasing in recent years. In particular, the share of imported petroleum in the total petroleum consumption has risen from $32 \%$ at the beginning of the 21 st century to $58 \%$ currently [5].

\subsection{Liquid Fuel Shortage in China Due to Transportation Increasing}

According to Wang [4], energy demand in China's transport sector increased from 25 Mtoe in 1980 to 206 Mtoe in 2009 with an average annual growth rate of $7 \%$, making the transport sector the fastest growing energy-consuming sector in China. Transport is also the fastest growing contributor to China's GHG emissions. Petroleum consumption in China transport sector was 223.2 Mtoe in 2010, with gasoline consumption at 67.6 Mtoe. The transport sector accounted for $35 \%-40 \%$ and $48 \%$ of petroleum consumption in China in 2000 and 2009, respectively, and is expected to rise to more than $50 \%$ in 2030, in line with global patterns [6]. Jet fuel demand increased to 19.44 million tons in China in 2012 with significant growth in air transport infrastructure accompanied by dramatic growth in aircraft usage [7].

\subsection{China is Developing Alternative Fuels on a Large Scale}

To curb oil demand, the Chinese government is making great efforts by regulating vehicle fuel economy and introducing alternative fuels, including coal- and NG-based fuels. For example, China has been promoting vehicles that operate on gaseous fuels, mainly compressed natural gas and liquefied petroleum gas, since 1999 [8,9]. China is also urgently developing and utilizing biofuels. As stated in its Energy Policy White Paper 2012, China will encourage the use of bio-diesel, ethanol and bio-jet fuel (BJF) [10]. 


\subsection{Life-Cycle Analysis is a Useful Tool for Policy Decision Making}

Life cycle GHG emissions have become critical and necessary information influencing the implementation of appropriate energy policies in an increasingly GHG-constrained world. Since the 1990s, researchers and institutions have begun to build life-cycle analysis (LCA) models to analyze energy consumption and GHG emissions. This has resulted in models such as The Greenhouse Gases, Regulated Emissions and Energy Use in Transportation Model (GREET) and Lifecycle Emissions Model (LEM) [11-15]. These models are able to evaluate alternative liquid fuels. A number of studies have been published for North America, Europe and other regions with localized conclusions, based these or similar models [16-21]. The conclusions are, however, very geographically dependent and therefore will not necessarily be applicable to other places.

Several LCAs have been performed for algae-based biofuel and biogas pathways, mostly in the United States and European context. Allen et al. [20] formulated the guidelines for LCA of aviation fuel in USA. Lardon et al. [21] analyzed life-cycle GHG emissions of algae-based bio-diesel in the European context and Clarens et al. [22] did a similar analysis for the USA. Campbell et al. [23] studied bio-diesel production from algae under Australian conditions. Collet et al. [24] examined the production of biogas from algae in France. The USA has been a global pioneer in algae biofuel research and engineering applications. With support from the US Department of Energy, the Argonne National Laboratory (ANL) performed LCA for hypothetical commercial projects [25]. The report of National Research Council of USA (NRC) [26] presented an extremely thorough review of the literature and findings up to the year 2012.

China's biofuel LCA studies [27] are mainly on non-algae based bio-ethanol and bio-diesel pathways except for the one by Hou et al. [28], which covered an algae-oil pathway. However, the data for micro-algae cultivation process in this paper are totally cited from studies for other country rather than China.

\subsection{Algae-Based Biofuel: Energy Positive or Not?}

In terms of life-cycle energy performance, algal fuels can be better than fossil fuels. However, there are no firm conclusions yet for this emerging technology. The NRC report [26] found that the energy return on investment (EROI) of pond-based algae can range from 0.13 to 7.0, based on a literature review. An EROI figure less than 1 means the energy needed to make a fuel is greater than the energy contained in the fuel and co-products. The ANL analysis [25] suggested that compared with conventional diesel, the use of algal bio-diesel may reduce life-cycle energy consumption by $55 \%$ and carbon emission by $45 \%$.

There are few LCA studies on algal BJF, except the PARTNER report [29] which covers life cycle GHG emissions from alternative BJF, including a simulated open-pond algae pathway. Its results show that the life cycle GHG emissions for algal BJF range from $16 \%$ to $220 \%$ of those from conventional jet fuel (CJF). The main source of variability in these results is due to the emerging nature of the algal fuel technology and many processes in the production systems are still in the laboratory or pilot phase. There is much uncertainty in how these technologies will evolve and scale up in the future. Therefore, 
actual life-cycle energy use and GHG emissions could be different from those suggested by existing LCA studies.

\subsection{About This Study}

As mentioned earlier, to the best knowledge of the authors there is no relatively in-depth LCA on algal BJF pathway under Chinese conditions. Therefore, the main objective of this paper is to assess life-cycle energy use and GHG emissions for algal BJF pathway specific to China in comparison with $\mathrm{CJF}$, the reference pathway. Meta-analysis in the NRC report [26] suggest the $\mathrm{CO}_{2}$ source and co-products are critical factors in the GHG balance. We develop our own process models to analyze the details under Chinese condition for key assumptions on water loss, $\mathrm{CO}_{2}$ source, co-product method and process fuel type, etc.

\section{Method and Data}

\subsection{Model Description}

In this study we used the Well-to-Wake (WTW) analysis module of the Tsinghua China LCA Model (TLCAM), which has been described in details elsewhere [29-32]. With the help of the iterative and source-tracing function of this model, all fuels and energy used in all sub-stages can be traced back to the use of three types of primary fossil energy (coal, natural gas and petroleum). Upstream emissions can be found in Li et al. [32]. Three key types of $\mathrm{GHG}-\mathrm{CO}_{2}, \mathrm{CH}_{4}$ and $\mathrm{N}_{2} \mathrm{O}-$ are taken into consideration and the 100-year global warming potential in $\mathrm{CO}_{2}$ equivalent $\left(\mathrm{CO}_{2, \mathrm{e}}\right)$ was calculated according to IPCC guidelines. In this study, a new module was developed to assess the life-cycle energy and GHG emissions for the algal BJF pathway. In this automated module, when key assumptions are changed, the final results with the initial changes are tracked and a visual output in the form of charts and graphs is generated.

\subsection{Life-Cycle Stages Covered and System Boundary}

As Figure 1 shows, five stages were included in this WTW energy consumption and GHG analysis. The first four stages are focused on the fuel production process, including the exploitation of raw resources, feedstock cultivation and transportation, fuel production and transportation, storage and distribution (TSD). The final stage is fuel combustion.

Some secondary-level energy use and GHG emissions for infrastructure building, labor input, vehicle and machinery manufacture are not considered as their contribution to the whole life-cycle results is expected to be small and can be omitted according to international LCA guideline. Both the transportation of water to the site and water movement onsite is included. $\mathrm{CO}_{2}$ transport to site and transfer to pond are also included.

The embodied energy of the materials used to construct the containment system in an algae pond is substantial. This is because the ratio of surface area to volume must be high in order to maximize light exposure and because the system must be completely isolated from surrounding ecosystems in order to protect the algae culture from predators as well as to prevent invasion of surrounding areas with non-native, perhaps genetically modified algae species [33]. In our base case, embodied energy of the 
pond construction materials are not considered, but an alternative scenario will be added in the sensitivity analysis.

Figure 1. Stages covered and system boundary in this study.

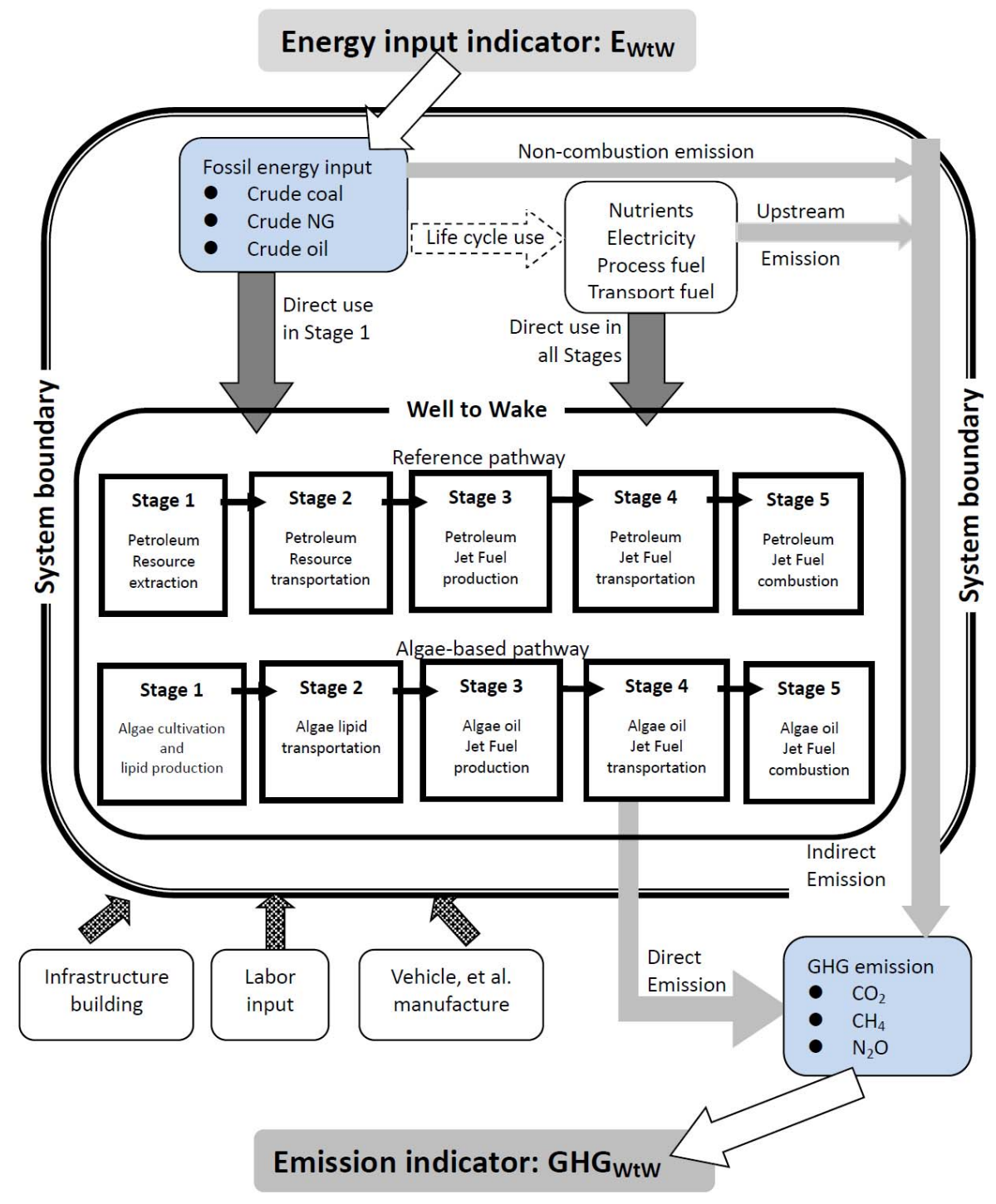

The function unit can be one $\mathrm{MJ}$ of algae oil produced and one MJ of jet fuel used, for energy functional and service functional units, respectively. In this study, there is not obvious difference of result comparison between energy functional and service functional unit based, due to that the energy performances of the two pathways (BJF and CJF) can be regarded as identical.

It is indicated that adding Bio-Synthetic Paraffinic Kerosene (Bio-SPK) has a minimal effect on the fuel consumption of airplanes. Therefore, in the fuel combustion stage, the energy performance for the two pathways can be regarded as identical. Clearly, comparative analyses of these pathways avoided the difficulties associated with specific airplane models [29,34].

\subsection{Reference Pathway}

The energy efficiency of petrochemical jet fuel refining was determined through literature surveys [29,35] in the China Automotive Energy Research Center (CAERC) report [36], which used 
top-down approach and assumed that the jet fuel-specific refining efficiency can be calculated from overall refinery efficiency using the equation developed by Wang et al. [37]. The life-cycle results of this pathway from [36] are summarized in Table 1.

Table 1. Life-cycle energy consumption and GHG emissions of the petrochemical jet fuel pathway in China [36].

\begin{tabular}{ccc}
\hline Item & Number & Unit \\
\hline Life-cycle fossil energy consumption & 1.26 & $\mathrm{MJ} / \mathrm{MJ}$ \\
Including: Coal & 0.07 & $\mathrm{MJ} / \mathrm{MJ}$ \\
Natural gas & 0.06 & $\mathrm{MJ} / \mathrm{MJ}$ \\
Petroleum & 1.13 & $\mathrm{MJ} / \mathrm{MJ}$ \\
Life-cycle GHG emissions & 93.5 & $\mathrm{~g} \mathrm{CO}, \mathrm{e} / \mathrm{MJ}$ \\
\hline
\end{tabular}

\subsection{Baseline Algal BJF Pathway}

Currently, algal biofuel technologies are under development or in partial technical demonstration. Existing projects are relatively small and the available data are not sufficiently representative. Consequently, LCA of this pathway is difficult.

In our study, a hypothetical commercial project is evaluated with some parameters specific to China (Table 2). The paddle wheel mixed open raceway ponds to cultivate planktonic algae are assumed to have a size of 100 ha, with flue gas $\left(20 \% \mathrm{CO}_{2}\right)$ supplied by nearby power plant under Chinese conditions [36]. The operation period is set to be 300 days annually.

Innovations that result in reduced resource use along the entire supply chain will remove some of the existing barriers to the development of large-scale, sustainable, and economically viable algal biofuels.

Algae productivity and lipid content are two key parameters and they are set as $25 \mathrm{~g} / \mathrm{m}^{2} /$ day and $25 \%$ in the baseline case, following Davis et al. [38]. Sensitivity analysis will explore the effects of a $50 \%$ reduction and a $100 \%$ increase in these values, considering that improvements in algae productivity and biofuel yield will help reduce resource requirements per unit algal biofuel produced.

Table 2. Key assumptions for algae cultivation system in China.

\begin{tabular}{ccc}
\hline Item & Properties & Note \\
\hline $\begin{array}{c}\text { Type of algae } \\
\text { cultivation system }\end{array}$ & Open raceway ponds & $\begin{array}{c}\text { Selected because of its lower cost and energy } \\
\text { consumption than the bioreactor system [26] }\end{array}$ \\
\hline $\begin{array}{c}\text { Scale of algae farm } \\
\text { and } \mathrm{CO}_{2} \text { source }\end{array}$ & A nearby power plant & $\begin{array}{c}\text { Based on primary bench-scale data and process modeling } \\
\text { in Kadam (2002) [39] which considered a coal power plant } \\
\text { with algae biomass using flue gas from the power plants. }\end{array}$ \\
\hline $\mathrm{CO}_{2}$ content of flue gas & $20 \mathrm{vol} \mathrm{\%}$ & CAERC report [36] \\
\hline Algae productivity & $25 \mathrm{~g} / \mathrm{m}^{2} /$ day & Davis et al. (2011) [38] \\
\hline Lipid content & $25 \%$ & Davis et al. (2011) [38] \\
\hline $\begin{array}{c}\text { Type of algae } \\
\text { oil extraction system }\end{array}$ & Wet extraction & $\begin{array}{c}\text { Extraction must be done onsite proximal } \\
\text { to the algae growth pond [40] }\end{array}$ \\
\hline
\end{tabular}

The core process model is elaborated in Figure 2. Following the cultivation stage, algae harvesting and oil extraction are done at the farm. The pathway dewaters the culture in several progressive steps 
including bio-flocculation, dissolved air flotation (DAF) and centrifugation, to manage energy consumption. Recent work of Vasudevan et al. [40] compared the energy input and GHG emissions of three kinds of algae lipid extraction technology: dry and wet extraction, and secretion. Wet hexane extraction is selected in this study because this process can be done onsite proximal to the pond and the thermal demand during this stage can be met with the CHP heat recovery as discussed later. Dry extraction is not selected due to the fact that the process of drying the wet biomass to about $10 \%$ moisture required more energy than was available in the harvest algae biomass as stated in [21], without considering the solar drying methods due to the disadvantages of large land footprint demand and possible climate constraints. After lipid fractionation process, the algae oil is then sent to a refinery for Bio-SPK production with jet fuel as the main product.

Figure 2. Baseline algae oil production process.

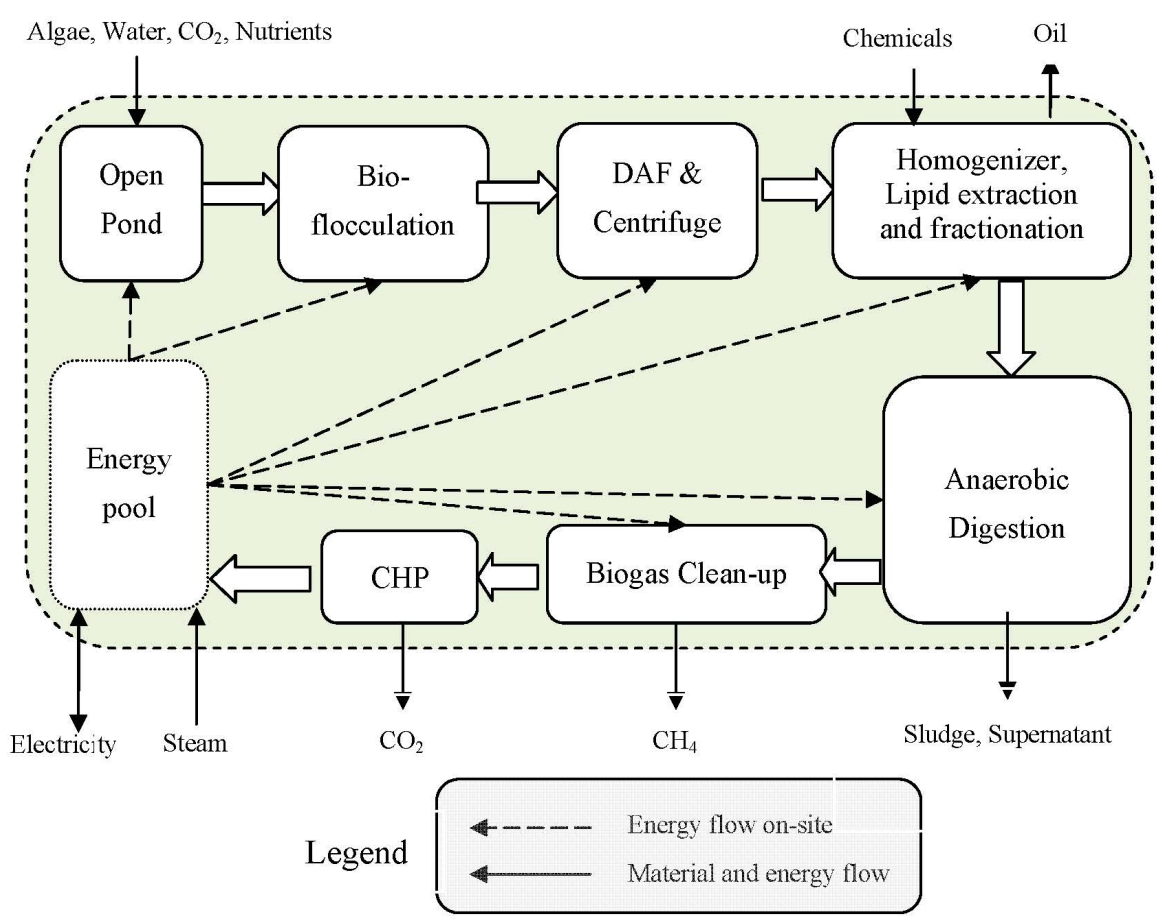

It is assumed that resources (algae, water, $\mathrm{CO}_{2}, \mathrm{~N}$, and $\mathrm{P}$ ) are recycled whenever possible through the processes at the farm. Inefficiencies in the homogenizer and in recovery during dewatering lead to flows of biomass, along with the lipid-extracted algae (LEA) after hexane extraction, to the anaerobic digester. Energy in these residues is partially recovered as biogas through anaerobic digestion (AD) and converted to electricity and steam by a combined heat and power (CHP) system on site. We assume certain amount of biogas leakage unavoidable.

In the model, heat and power from the CHP is available for use onsite (e.g., for AD and biogas cleaning, and algae cultivation and harvesting). Excess power (if available) is exported as co-products while excess heat is discarded. Electricity from the grid and heat produced onsite from coal with an energy efficiency of $75 \%$ will be used if there are deficits of power and heat for the system. Residue from biogas production is sold to external parties to replace chemical fertilizers. The details for all stages will be demonstrated in Section 3.1. 


\subsection{Energy and GHG Intensity of Process Fuels and Nutrients}

Analysis by $\mathrm{Li}$ et al. [32] (Table 3) assessed the fossil energy intensity and GHG emissions intensity of process fuels in China. In the BJF pathway module, we use these data to convert the direct energy use into life-cycle energy use. The fossil energy intensity $\left(E F_{L C}, \mathrm{MJ} / \mathrm{MJ}\right)$ and $\mathrm{GHG}$ emissions intensity $\left(G H G_{L C}, \mathrm{~g} \mathrm{CO}_{2, e} / \mathrm{MJ}\right)$ of a specific type of process fuel are defined as the sum of all the fossil energy use and GHG emissions, respectively, during the entire fuel life cycle for $1 \mathrm{MJ}$ final fuel obtained and utilized. Table 3 shows the life-cycle fossil energy and GHG emission intensity for the nine types of secondary energies (SE).

Table 3. Fossil energy and GHG emission intensity results of process fuel in China [32].

\begin{tabular}{|c|c|c|c|c|c|c|c|c|}
\hline \multirow{2}{*}{ Item } & \multirow{2}{*}{$E F_{L C}$} & \multicolumn{3}{|c|}{ By sort } & \multirow{2}{*}{$G H G_{L C}$} & \multicolumn{3}{|c|}{ Upstream emission } \\
\hline & & $E F_{L C, \text { Coal }}$ & $E F_{L C, N G}$ & $E F_{L C, \text { Petrol }}$ & & $\mathrm{CO}_{2, u p}$ & $\mathrm{CH}_{4, u p}$ & $\mathrm{~N}_{2} \mathrm{O}_{u p}$ \\
\hline Units & \multicolumn{4}{|c|}{$\mathrm{MJ} / \mathrm{MJ}$} & $\mathrm{g} \mathrm{CO}_{2, \mathrm{e}} / \mathrm{MJ}$ & $\mathrm{g} / \mathrm{MJ}$ & $\mathrm{g} / \mathrm{MJ}$ & $\mathrm{mg} / \mathrm{MJ}$ \\
\hline Coal & 1.172 & 1.061 & 0.001 & 0.110 & 104.5 & 5.733 & 0.425 & 0.172 \\
\hline Natural gas & 1.196 & 0.081 & 1.015 & 0.065 & 72.73 & 13.544 & 0.110 & 0.161 \\
\hline Diesel & 1.319 & 0.156 & 0.027 & 1.119 & 102.4 & 28.287 & 0.078 & 0.441 \\
\hline Gasoline & 1.331 & 0.164 & 0.049 & 1.130 & 98.86 & 30.506 & 0.086 & 0.472 \\
\hline Electricity & 2.924 & 2.572 & 0.021 & 0.330 & 289.6 & 273.308 & 1.010 & 3.917 \\
\hline
\end{tabular}

The data in Table 4 serve as multipliers for the corresponding process fuels used during each stage to obtain final life-cycle energy use and GHG emissions. The upstream emissions include those from all stages other than final use, i.e., from resource extraction and transport, to fuel conversion and transport. For example, the energy efficiencies of resource extraction and processing for coal ( $97 \%$ and $96 \%$, respectively) are higher than those for NG (96\% and 94\%, respectively) in China. Therefore, the upstream emissions of coal are high than those of NG. However, final life-cycle emissions of coal are higher than those of NG because of the higher carbon content of coal. Life-cycle fossil energy and GHG results for nutrients and chemicals in China are taken from [41] and listed in Table 4.

Table 4. Life-cycle fossil energy and GHG results for nutrients and chemicals [41].

\begin{tabular}{ccccccc}
\hline Item & Unit & $\mathbf{N}$ & $\mathbf{P}$ & $\mathbf{K}$ & Steam (from coal) & $\mathbf{H}_{2}$ (from coal) \\
\hline Lifecycle fossil Energy & $\mathrm{MJ} / \mathrm{kg}$ & 55.17 & 7.98 & 8.90 & 1.56 & 1.78 \\
Of which, Coal & $\mathrm{MJ} / \mathrm{kg}$ & 41.52 & 3.01 & 5.71 & 1.41 & 1.76 \\
Natural gas & $\mathrm{MJ} / \mathrm{kg}$ & 7.83 & 4.25 & 1.14 & 0.00 & 0.00 \\
Petroleum & $\mathrm{MJ} / \mathrm{kg}$ & 5.55 & 0.58 & 2.01 & 0.15 & 0.02 \\
Lifecycle GHG & $\mathrm{g} \mathrm{CO}_{2, \mathrm{e}} / \mathrm{kg}$ & 5148 & 587 & 811 & 139 & 163 \\
\hline
\end{tabular}

\section{Results and Discussion}

\subsection{Detailed Analysis of All Stages}

\subsubsection{Algae Farming}

As Table 2 shows, in this hypothetical open pond farm, the algae growth rate was assumed to be $25 \mathrm{~g} / \mathrm{m}^{2} /$ day, and the lipid content of the produced algae assumed to be $25 \%$ in the baseline case, 
and the farm was assumed to operate 300 days a year. Consequently, 1 ha of pond area yields $75 \mathrm{t}$ of algae biomass $(75=25 \times 300 / 100)$ annually.

Algae growth and bio-flocculation account for almost all water movement in the system. Water movement occurs when the ponds are mixed to keep the algae in suspension, when culture is moved for settling, when the supernatant is recycled to the pond, and when water lost due to evaporation and soil leakage is replaced.

An earlier study [41] reported that $2000 \mathrm{~W}$ of electric power is required to maintain $30 \mathrm{~cm} / \mathrm{s}$ stirring movement for 1 ha of pond area. For the hypothetical farm in the present study, this translates into a power requirement of $24 \mathrm{kWh} / \mathrm{ha} /$ day if the circulation system is run $12 \mathrm{~h}$ per day on average. Therefore, $\sim 96 \mathrm{kWh}$ of electricity is consumed due to water circulation for $1 \mathrm{t}$ of algae biomass production. This value is higher than the water circulation energy use of $76 \mathrm{kWh} / \mathrm{t}$ algae in Murphy and Allen [33].

When the algae concentration reaches $0.5 \mathrm{~g} / \mathrm{L}$, the culture will be pumped to the settling pond for bio-flocculation. Water recovery from bio-flocculation is assumed to be $100 \%$ except for the water that flows downstream with the algae at $10 \mathrm{~g} / \mathrm{L}$ of concentration. In this study, water is returned to the culture pond from settling pond without loss and future work will consider these losses. Therefore, pumping of 3900 tons of water to the settling pond and back to culture pond is required for $1 \mathrm{t}$ of algae biomass production. A study [42] on detailed process design cost estimation using Computer Assisted Procedure for Design and Evaluation of Wastewater Treatment Systems (CAPDET) reported that $4.8 \times 10^{-5} \mathrm{kWh}$ of electricity is required for pumping $1 \mathrm{~L}$ of water at a head of 5 feet. Based on this value, $\sim 195 \mathrm{kWh}$ of electricity is consumed by water pumping for $1 \mathrm{t}$ of algae biomass production at our farm.

As Murphy and Allen [43] stated, in order to achieve mean daily production rates of $25 \mathrm{~g} / \mathrm{m}^{2} /$ day, the algae has to be grown in a semi-continuous system. This requires significant volumes of water to be pumped through very small diameters in a short period of time, requiring significant amounts of energy. The final result is $1450 \mathrm{kWh} / \mathrm{t}$ algae in Murphy and Allen [33], which will be used for the alternative case in the sensitivity analysis.

The water replenishment rate is about $0.6 \mathrm{~cm}$ per operating day considering the average pan evaporation rate is $0.3 \sim 0.4 \mathrm{~cm} /$ day in China [44] and water leakage from the pond to the surrounding soil is $0.11 \sim 0.36 \mathrm{~cm} /$ day as Murphy and Allen [33] discussed. Base on the water balance in Figure 3, about $344 \mathrm{t}$ of water is made-up for $1 \mathrm{t}$ of algae biomass production. The energy consumption for fresh water acquirement in China is $\sim 0.19 \mathrm{kWh}$ for surface water and $0.49 \mathrm{kWh}$ for ground water [34], which are less than those in USA (0.42 and 1.00 respectively [33]). We use the averages of these values to calculate the energy consumption for fresh water acquirement. Therefore, $\sim 112 \mathrm{kWh}$ of electricity is consumed due to fresh water acquirement for $1 \mathrm{t}$ of algae biomass production. In addition, in our analysis the fresh water intensity of algae production is $340 \mathrm{t} / \mathrm{t}$ in the baseline case, less than the level in USA (780 t/t by Murphy and Allen [33]). So the value in our study (112 kWh/t algae) is much lower than that for USA (326 kWh/t algae).

In total, $\sim 406 \mathrm{kWh}$ of electricity is consumed due to water movement for $1 \mathrm{t}$ of algae biomass production. As energy consumption during algae cultivation is primarily for mixing and pumping water, Murphy and Allen [33] suggested the energy needs for water management could be substantially higher than current LCA studies indicate. We will test the impact of different water consumption rates and the associated energy consumption rate in the alternative case. 
Figure 3. Water balance during algae growth and harvesting (ton of water per dry-ton of algae production).

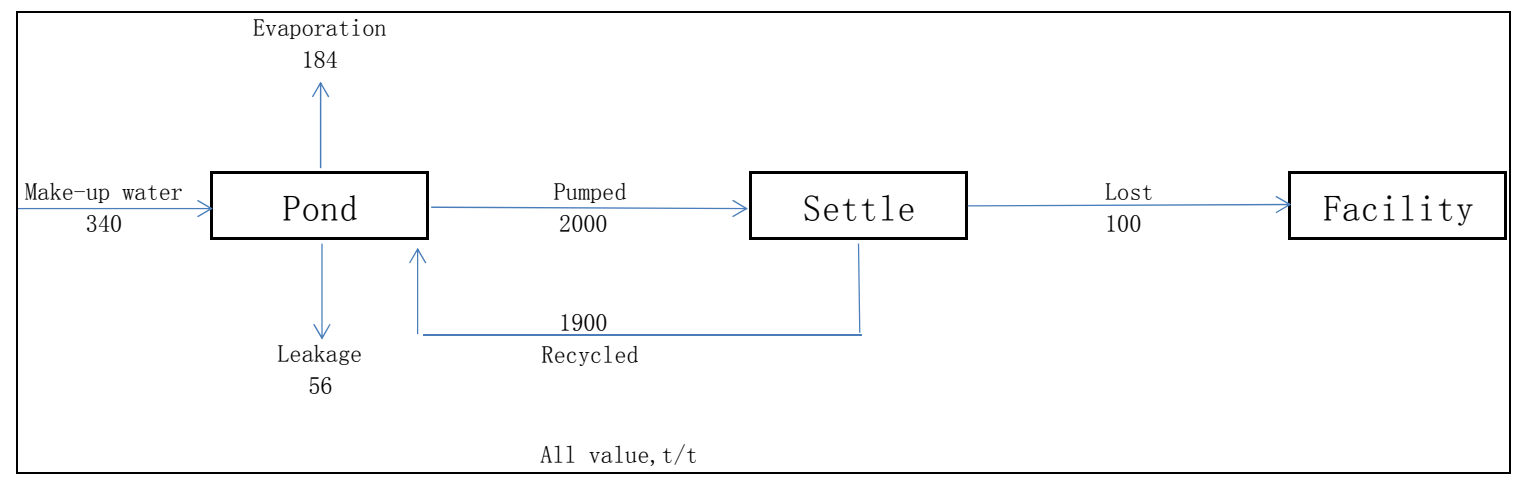

(1) Carbon input and Related Electricity Consumption

The carbon content of the algae biomass was assumed to be approximately $50 \%$. Therefore, the $\mathrm{CO}_{2}$ demand ratio was 1.83. Further assuming a $\mathrm{CO}_{2}$ use efficiency of 0.85 , the overall $\mathrm{CO}_{2}$ demand ratio was 2.16. As shown in Figure 4, recovered $\mathrm{CO}_{2}$ from the $\mathrm{CHP}$ system and offsite $\mathrm{CO}_{2}$ are 0.70 $(0.70=0.19 \times 44 / 12)$ and $1.45(1.45=0.40 \times 44 / 12)$ ton of $\mathrm{CO}_{2}$ for $1 \mathrm{t}$ of algae biomass production, respectively. As stated in section 2.4, in this study, the off-site $\mathrm{CO}_{2}$ demand was met by transporting flue gas with $20 \% \mathrm{CO}_{2}$ vol \% from a nearby power plant.

Figure 4. Carbon flows of the algae pathway.

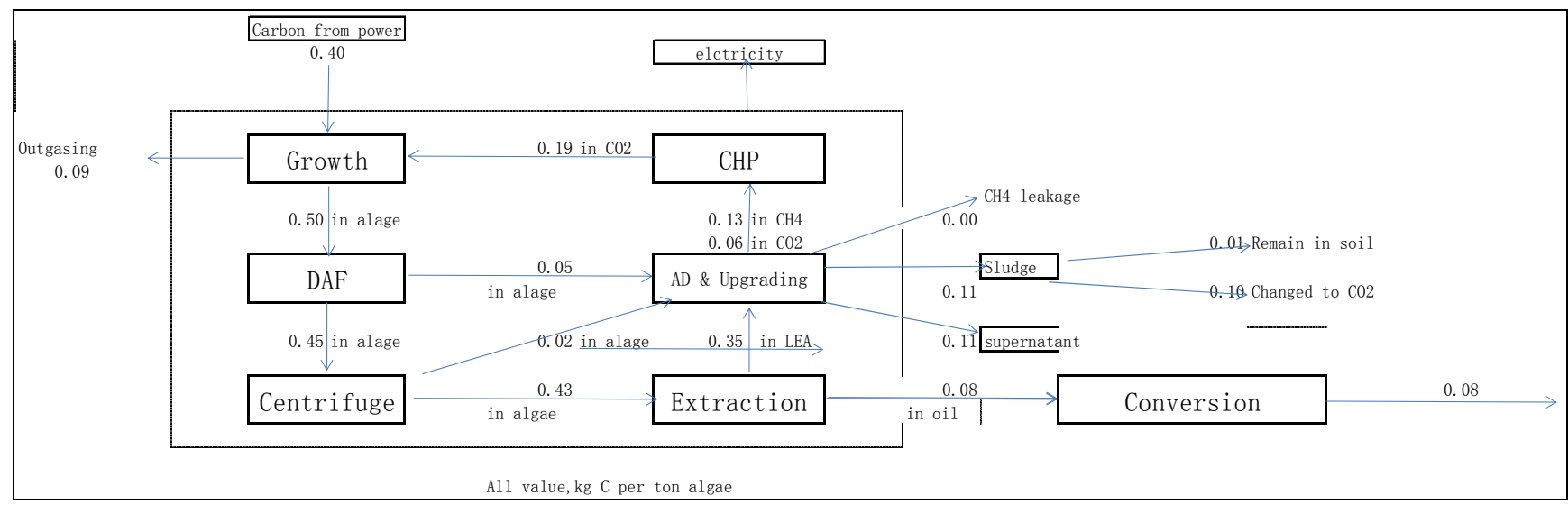

Calculation using GREET [25] showed that $11.6 \mathrm{kWh}$ of electrical energy was required for transporting $1 \mathrm{t}$ of $\mathrm{CO}_{2}$ (the overall efficiency of the compressors and motors was assumed to be approximately 50\%). In addition, $21.2 \mathrm{kWh}$ of electrical energy was required for injecting $1 \mathrm{t}$ of $\mathrm{CO}_{2}$ into the culture with a pressure drop of 1.5 meter water equivalent (corresponding to transfer sump depth, the combined efficiency of 0.67).

To sum up, the electricity for carbon input is about $62.7 \mathrm{kWh}$ for $1 \mathrm{t}$ of algae biomass production. About three quads of them are used for $\mathrm{CO}_{2}$ injection and only one quad is used to transport offsite flue gas to the algae farm.

According to Jaramillo et al. an additional $180 \sim 140 \mathrm{kWh}$ of electricity per ton of compressed $\mathrm{CO}_{2}$ is consumed to fully capture the $\mathrm{CO}_{2}$ produced in the coal chemical plant. This method will be used to study sensitivities later. 


\section{(2) Nutrients Input}

In our farm, the nutrients were urea and DAP (diammonium phosphate) and about $5 \%$ of nitrogen to volatilization. As analyzed in Figure 5 in Section 3.3, it was determined that the production of $1 \mathrm{~g}$ of algae required $14 \mathrm{mg}$ of $\mathrm{N}$ and $6.3 \mathrm{mg}$ of $\mathrm{P}$ (both expressed in masses of the pure elements), with recovered nutrients (42.2 $\mathrm{mg}$ of $\mathrm{N}$ and $6.3 \mathrm{mg}$ of $\mathrm{P}$ ), to satisfy the gross nutrient demand per dry gram of algae (55.5 mg of $\mathrm{N}$ and $12.6 \mathrm{mg}$ of $\mathrm{P}$ ), after $0.7 \mathrm{mg}$ of $\mathrm{N}$ loss in volatilization, which based on a $\mathrm{C}: \mathrm{N}: \mathrm{P}$ composition of 103:10:1 and nutrients are assumed to be consumed stoichiometrically.

\subsubsection{Algae Harvesting}

DAF is selected as the first step for algae harvest with $90 \%$ of algae is retained while the balance is sent to the anaerobic digester. The second centrifugation process has an efficiency of $95 \%$, and the residual algae mass was sent for $\mathrm{AD}$ too. Therefore, $1.17 \mathrm{~g}$ of harvested algae mass was required to produce $1 \mathrm{~g}$ of dewatered algae mass after dewatering processes including DAF and centrifugation. For the production of 1 dry-gram of dewatered algae mass for oil extraction, there is $1.33 \times 10^{-4} \mathrm{kWh}$ and $1.0 \times 10^{-3} \mathrm{kWh}$ of electrical energy consumption for DAF process and centrifugation, respectively $[42,45]$. While Uduman et al.'s [46] estimate for this number was 10 times higher $\left(8.0 \times 10^{-3} \mathrm{kWh}\right)$ and Mohn [45] also estimated for this number was eight times higher $\left(1.67 \times 10^{-3} \mathrm{kWh}\right)$. The sensitivity analysis on this variation of centrifugal method will show us whether the algae fuel is energy positive or not. We can find the harvest energy is about $1155 \mathrm{kWh}$ of electricity for $1 \mathrm{t}$ of algae biomass harvested.

In early foundational works like Benemann and Oswald [47], the algae was dried before centrifuge stage and favored a hot oil extraction to extract oil directly. However, this kind of expensive energy and cost investment is not selected and the algae biomass is not dried prior to the hexane solvent extraction in our study as discussed in Section 2.4.

\subsubsection{Oil Extraction}

Oil is extracted from the dewatered algae mass (20\% solid content) by a high-pressure homogenization process, which was assumed to use $0.2 \mathrm{kWh}$ of electrical energy for processing $1 \mathrm{~kg}$ of dry mass [48]. The disruption efficiency was assumed to be $90 \%$, and the un-homogenized algae mass entered the LEA for AD. The following process of hexane extraction is assumed to give a lipid extraction efficiency of $95 \%$ and require the following resources (for producing $1 \mathrm{~kg}$ of lipid): $6.12 \mathrm{MJ}$ of heat, $0.54 \mathrm{kWh}$ of electrical energy, and $5.2 \mathrm{~g}$ of $n$-hexane. So the electricity and heat demand are about $774 \mathrm{kWh}$ and $6120 \mathrm{MJ}$ for $1 \mathrm{t}$ of algae oil produced. There is a concern that phospholipids and other non-TAGs can account for sizable portions of the lipid fraction. To get the desired neutral lipids, lipid fractionation processes such as acid addition, water wash and degumming are required to minimize the phosphors and water content [49]. Although the energy use during this lipid fractionation stage is negligible (less than $1 \%$ that of algae harvest stage), the oil loss of about $2.77 \%$ needs to be considered. The thermal demand during this stage is met with the CHP heat recovery as discussed later. 


\subsubsection{AD, Biogas Cleaning and CHP}

We assume the LEA undergoes AD to produce energy and recycle nutrients to algae culture. Energy generation form AD contributes to reducing energy input and hence GHG emissions. Mass balance analyses indicated that during lipid extraction, the production of $1 \mathrm{t}$ of algae oil was accompanied by the generation of $4.47 \mathrm{t}$ of mixture of LEA and algae loss from harvest, which was subsequently used as a raw material for $\mathrm{AD}$.

It was assumed that, the AD raw material consisted of primarily (90\%) suspended matter. According to a previous study on $\mathrm{AD}$ [50], $1 \mathrm{~g}$ of suspended matter produces 0.33 liters of methane, and $1 \mathrm{t}$ of solid input yields $2.97 \times 10^{5} \mathrm{~m}^{3}$ of methane. Assuming the biogas produced at our farm consisted of $67 \%$ methane and $33 \% \mathrm{CO}_{2}$, the conversion relationship became: $1 \mathrm{t}$ of solid input producing $287 \mathrm{~kg}$ of biogas. Considering the reality of the $\mathrm{AD}$ process and the following biogas cleaning, approximately $2 \%$ of $\mathrm{CH}_{4}$ was assumed to be lost via leakage. For $1 \mathrm{~kg}$ of solid input, the AD process requires $2.448 \mathrm{MJ}$ of heat or $0.136 \mathrm{kWh}$ of electrical energy. Additionally, for the production of $1 \mathrm{~m}^{3}$ of biogas, another $0.25 \mathrm{kWh}$ of electrical energy is required for product purification-upgrading [51].

The generated and cleaned biogas was used by CHP to produce heat and electrical energy. Assuming an overall energy efficiency of $76 \%$ and electrical energy generation efficiency of $33 \%$, with the methane produced from 1 ton of solid is inputted $(10,439 \mathrm{MJ})$ into the CHP process, this system should produce $956 \mathrm{kWh}$ of electrical energy and $4486 \mathrm{MJ}$ of heat.

Overall, besides the supplying electricity and heat for AD and biogas cleaning, the production of $1 \mathrm{t}$ of algae lipid is accompanied by the generation of $3336 \mathrm{kWh}$ of electrical energy and $9113 \mathrm{MJ}$ of heat. These heat and power is available for use onsite (e.g., algae cultivation, harvest and lipid extraction).

\subsection{Carbon Balance}

Figure 4 shows the carbon flows at each stage of the algal BJF pathway. About 2.16 tons of $\mathrm{CO}_{2}$ is transferred into the pond with $\sim 15 \%$ of outgas. After the DAF, centrifuge and lipid extraction stages, only $16 \%$ of carbon in the algae is re-carbonated into the oil. The remaining $84 \%$ is allocated to the $\mathrm{AD}$ process "products": biogas $\left(\mathrm{CH}_{4}\right.$ and $\left.\mathrm{CO}_{2}\right)$ cleaned for the $\mathrm{CHP}$, leaked $\mathrm{CH}_{4}$, sludge and supernatants. The last two "products" are assumed to have equal amount of the rest of carbon other than in biogas and leaked $\mathrm{CH}_{4}$. It was further assumed that $8 \%$ of carbon in the sludge was sequestrated into the soil while the other $92 \%$ gradually released as $\mathrm{CO}_{2}$ over a long period. About $38 \%$ of carbon in the algae biomass will be in the recyclable $\mathrm{CO}_{2}$ contained in the flue gas of the onsite CHP system, and they are equal to about half of the external $\mathrm{CO}_{2}$ supplied. It was found that only $\sim 23 \%$ of carbon in the external flue gas supplied can be re-carbonated into the oil $(\sim 20 \%)$ and sequestrated into the soil $(\sim 3 \%)$.

\subsection{Nutrients Balance}

Based on a C:N:P composition of 103:10:1, nutrients are assumed to be consumed stoichiometrically. It is also assumed the volatilization rate of nitrogen fertilizers is $\sim 5 \%$. As Figure 5 shows, $14 \mathrm{mg}$ of $\mathrm{N}$ and $6.3 \mathrm{mg}$ of $\mathrm{P}$ with recovered nutrients $(42.2 \mathrm{mg}$ of $\mathrm{N}$ and $6.3 \mathrm{mg}$ of $\mathrm{P}$ ) is required to satisfy the gross nutrient demand per dry gram of algae (56.2 $\mathrm{mg}$ of $\mathrm{N}$ and $12.6 \mathrm{mg}$ of $\mathrm{P}$ ), with $0.7 \mathrm{mg}$ of $\mathrm{N}$ lost in 
volatilization. There are $55.5 \mathrm{mg}$ of $\mathrm{N}$ and $12.6 \mathrm{mg}$ of $\mathrm{P}$ (for $1 \mathrm{~g}$ of algae produced) entering $\mathrm{AD}$ to form sludge and liquid.

$80 \%$ of $\mathrm{N}$ was recovered through supernatant recycling but $5 \%$ of the recovered $\mathrm{N}$ was lost via leakage. It was assumed that $50 \%$ of the $\mathrm{P}$ in the liquid phase was recovered with the other $50 \%$ left in the sludge. Therefore, the sludge contains $11.1 \mathrm{mg}$ of $\mathrm{N}$ and $6.3 \mathrm{mg}$ of $\mathrm{P}$, and the liquid contained $44.4 \mathrm{mg}$ of $\mathrm{N}$ and $6.3 \mathrm{mg}$ of $\mathrm{P}$ (for $1 \mathrm{~g}$ of algae produced). Nutrients in the liquid were subsequently recycled with $\mathrm{N}$ partially recycled and $\mathrm{P}$ totally recycled. Overall, the recovery rates of $\mathrm{N}$ and $\mathrm{P}$ are $75 \%$ and $50 \%$, respectively.

Figure 5. $\mathrm{N}$ and $\mathrm{P}$ flows of the algae pathway.

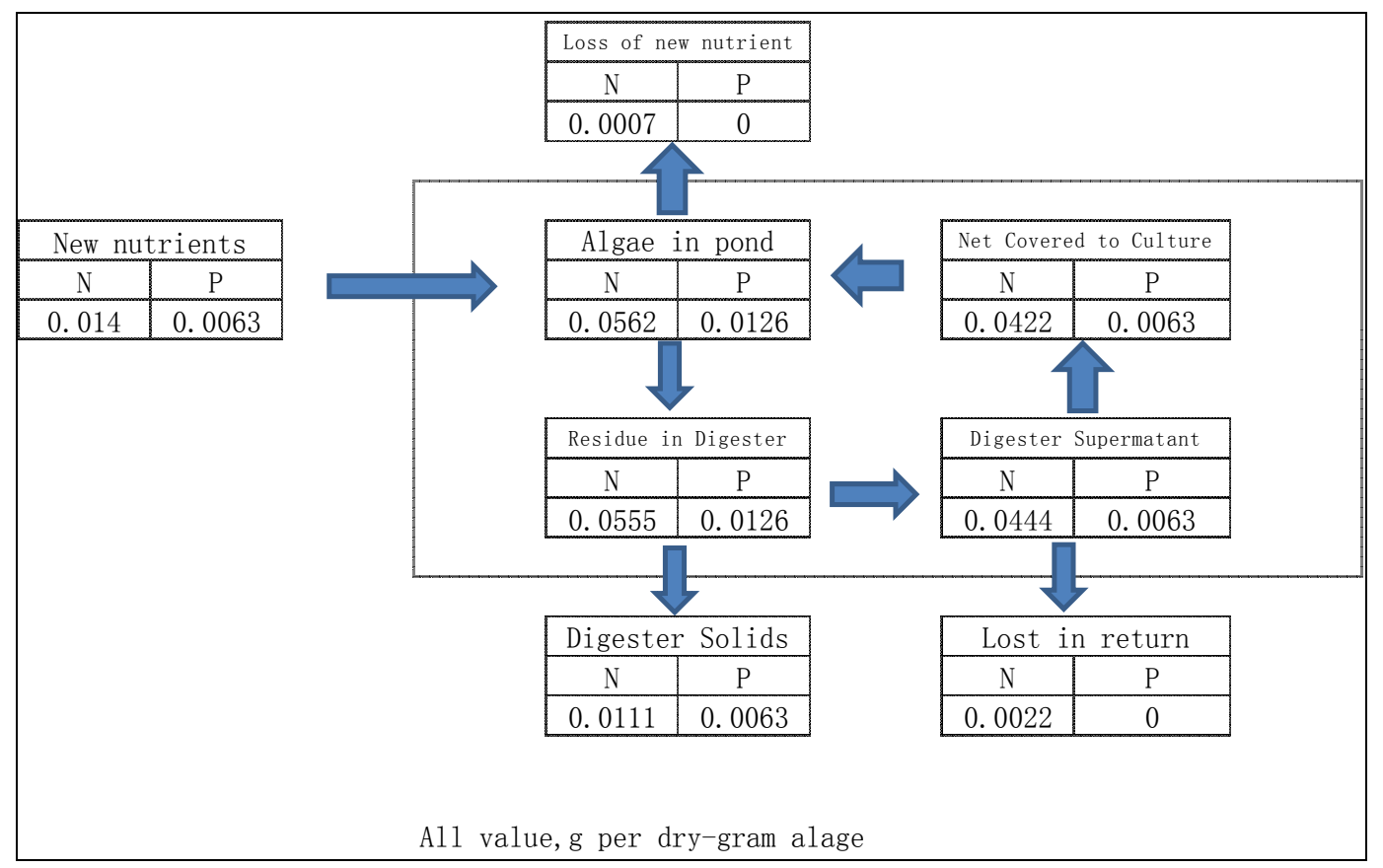

\subsection{Non- $\mathrm{CO}_{2}$ GHG Emissions}

There are two potential sources for $\mathrm{CH}_{4}$ emissions in the algae pathway, the AD process and biogas clean-up. Based on a literature review [52], we assume a total fugitive $\mathrm{CH}_{4}$ loss of $2 \%$ for this pathway.

The $\mathrm{N}_{2} \mathrm{O}$ emission from the $\mathrm{N}$-containing sludge was ignored because chemical fertilizers replaced by the biogas residue are associated with the same issue.

\subsection{Direct Energy Demand}

The direct heat and power demand for the baseline case is shown in Table 5. 
Table 5. Direct energy and $\mathrm{CO}_{2}$ demand for process on site in basic case.

\begin{tabular}{|c|c|c|c|c|c|c|c|c|}
\hline \multirow{2}{*}{$\begin{array}{c}\text { Item } \\
\text { Process }\end{array}$} & \multirow{2}{*}{\multicolumn{2}{|c|}{$\begin{array}{c}\text { Unit } \\
\text { Process input }\end{array}$}} & \multicolumn{4}{|c|}{ Direct energy demand } & \multicolumn{2}{|c|}{$\mathrm{CO}_{2}$ demand } \\
\hline & & & Thermal (MJ) & Electrical (kWh) & Thermal (MJ) & Electrical (kWh) & per kg algae & per kg of algae lipid \\
\hline Growth & & - & per kg algae & per kg algae & per kg of algae lipid & per $\mathrm{kg}$ of algae lipid & 2.16 & 11.80 \\
\hline water circulation & 2.00 & kW per ha & - & 0.096 & - & 0.53 & - & - \\
\hline water pumping & 3.90 & $\mathrm{t}$ per kg algae & - & 0.195 & - & 1.07 & - & - \\
\hline water replenishment & 0.60 & $\mathrm{~cm}$ per day & - & 0.116 & - & 0.63 & - & - \\
\hline Off-site $\mathrm{CO}_{2}$ transport to onsite & - & - & - & 0.017 & - & 0.09 & 1.45 & 7.95 \\
\hline Off-site $\mathrm{CO}_{2}$ transfer into pond & - & - & - & 0.031 & - & 0.17 & 1.45 & 7.95 \\
\hline Recovered $\mathrm{CO}_{2}$ transfer into pond & - & - & - & 0.015 & - & 0.08 & 0.70 & 3.85 \\
\hline \multirow{2}{*}{ Harvest } & \multirow{2}{*}{1.17} & \multirow{2}{*}{$\mathrm{kg}$ algae $/ \mathrm{kg}$ dewatered algae } & \multirow{2}{*}{-} & per kg dewatered algae & \multirow{2}{*}{-} & per kg of algae lipid & \multirow{2}{*}{-} & \multirow{2}{*}{-} \\
\hline & & & & 1.16 & & 5.41 & & \\
\hline \multirow{2}{*}{ Lipid extraction } & \multirow{2}{*}{4.68} & \multirow{2}{*}{$\begin{array}{c}\text { kg dewatered } \\
\text { algae/kg lipids }\end{array}$} & per kg lipids & per kg lipids & per $\mathrm{kg}$ of algae lipid & per kg of algae lipid & \multirow{2}{*}{-} & \multirow{2}{*}{-} \\
\hline & & & 6.12 & 0.77 & 6.12 & 0.77 & & \\
\hline \multirow{2}{*}{ Anaerobic digester } & \multirow{2}{*}{4.47} & \multirow{2}{*}{$\mathrm{kg}$ feed/kg lipids } & per kg feed & per $\mathrm{kg}$ feed & per kg of algae lipid & per kg of algae lipid & \multirow{2}{*}{-} & \multirow{2}{*}{-} \\
\hline & & & 2.45 & 0.14 & 10.95 & 0.61 & & \\
\hline \multirow{2}{*}{ Biogas cleanup } & \multirow{2}{*}{0.297} & \multirow{2}{*}{ cubic meter $/ \mathrm{kg}$ feed } & \multirow{2}{*}{-} & per cubic meter & \multirow{2}{*}{-} & per kg of algae lipid & \multirow{2}{*}{-} & \multirow{2}{*}{-} \\
\hline & & & & 0.25 & & 0.33 & & \\
\hline Total direct demand on site & - & - & - & - & 17.07 & 9.69 & - & - \\
\hline \multirow{2}{*}{ Recovered on site (CHP) } & $76 \%$ & CHP efficiency & per MJ CH4 & per MJ CH4 & per kg of algae lipid & per kg of algae lipid & \multirow{2}{*}{-} & \multirow{2}{*}{-} \\
\hline & 35.8 & $\mathrm{MJ} /$ cubic meter & 0.43 & 0.09 & 20.45 & 4.36 & & \\
\hline Imported externally & - & - & - & - & -3.38 & 5.33 & - & - \\
\hline
\end{tabular}


Some relationships between them are listed as follows:

\section{(1) Algae Dewatering and Oil Extraction}

The biomass recovery efficiencies of the first and second dewatering processes were $90 \%$ and $95 \%$ (the remnant of the dewatering processes processed by $\mathrm{AD}$ ). Correspondingly, the conversion from harvested algae to dewatered algae was $1 \mathrm{t}$ of algae harvested yielding $0.86 \mathrm{t}$ of dewatered algae $(0.86=0.9 \times 0.95)$, with the conversion rate being $1.17 \mathrm{~kg}$ algae $/ \mathrm{kg}$ dewatered algae

The lipid content of harvested algae was assumed to be $25 \%$ in baseline case. The lipid destruction and oil recovery efficiencies during the first and second lipid extraction processes were assumed to be $90 \%$ and $95 \%$, respectively. Therefore, the conversion from harvested algae to algae lipid was $1 \mathrm{t}$ of algae biomass yielding $0.21 \mathrm{t}$ of algae lipid $(0.21=0.25 \times 0.9 \times 0.95)$, with the conversion rate being $4.68 \mathrm{~kg}$ algae biomass $/ \mathrm{kg}$ lipids. It is noted that a further $2.77 \%$ of oil will be lost during the final degumming stage for lipid fractionation and this loss will be accounted for in the jet fuel production process for the convenience of calculation method in this study.

(2) Mass Relationship between the AD Raw Material and Algae Oil Product

Mass balance calculations indicated that the mass of lipid-extracted algae (LEA) entering the AD process was (theoretically) 4.47 times the mass of the algae lipid $(4.47=5.47-1)$. In practice, this is only 3.68 times the algae lipid mass. Moreover, some of the algae mass resulting from dewatering processes also entered AD. Combining these, the mass entering AD was 4.47 times the algae lipid mass.

(3) External $\mathrm{CO}_{2}$ Input

The total demand for $\mathrm{CO}_{2}$ was $2.16 \mathrm{~kg} \mathrm{CO}_{2} / \mathrm{kg}$ algae, or $11.80 \mathrm{~kg} \mathrm{CO}_{2} / \mathrm{kg}$ algae lipid. However, a considerable fraction of $\mathrm{CO}_{2}$ could be recovered ( $3.85 \mathrm{~kg} \mathrm{CO}_{2} / \mathrm{kg}$ algae lipid) from the $\mathrm{AD}$ and CHP processes. Consequently, $8.81 \mathrm{~kg}$ of external $\mathrm{CO}_{2}$ was required for $1 \mathrm{~kg}$ of algae lipid produced.

\subsection{Jet Fuel Production}

There are various technologies to produce aviation biofuel currently and two of them have been included in the ASTM D7566 standard: the hydrotreating process and the Fischer-Tropsch (FT) synthesis process [36]. In this study, the extracted algae oil is assumed to be processed into jet fuel using the UOP Renewable Jet Process technique. This kind of hydro-treated renewable jet fuel has similar compositions and combustion properties to petrochemical synthetic paraffinic kerosene (SPK). In July 2011, the ASTM gave final approval for blending of SPK from Hydro-processed Esters and Fatty Acids (HEFA) up to $50 \mathrm{vol} \%$ in aviation fuels, thus facilitating a commercial pathway to sustainable aviation fuels.

The overall energy efficiency of converting algae oil to jet fuel is $\sim 85 \%$ according to [36], which is consistent with the data provided in a 2010 report [32] and is therefore used in this study. Beside the algae oil $(0.90 \mathrm{MJ})$ as the main input, $0.15 \mathrm{MJ}$ of $\mathrm{NG}, 0.12 \mathrm{MJ}$ of $\mathrm{H}_{2}$, and $0.004 \mathrm{MJ}$ of electricity are also required to produce $1 \mathrm{MJ}$ of fuel product. The main fuel product is jet fuel (about $50 \%$ of total output), with a small amount of naphtha and biodiesel co-produced. In this study, the method used in dealing with these co-products is energy allocation. 


\subsection{Co-Products, Oil and Fuel Transportation}

Transportation of co-products, algae oil, and final jet fuel is summarized in Table 6. AD digestate solids (assuming $30 \mathrm{wt} \%$ solids in water) are transported by medium heavy-duty truck over a distance of $100 \mathrm{~km}$ for field application. Algae oil is transported by rail over a distance of $1000 \mathrm{~km}$ to reach a refinery facility. The transportation modes and distributions for final BJF exactly match those used for CJF pathway.

Table 6. Co-products, oil and fuel transportation information [53].

\begin{tabular}{ccccc}
\hline Product/Intermediate & Mode & $\begin{array}{c}\text { Energy Intensity (MJ/t km, } \\
\text { backhaul of the vehicle } \\
\text { includes when appropriate) }\end{array}$ & $\begin{array}{c}\text { Fuel mix } \\
\mathbf{( \% )}\end{array}$ & $\begin{array}{c}\text { Distance } \\
\text { (km) }\end{array}$ \\
\hline $\begin{array}{c}\text { Digestate solids } \\
\text { transported to fields }\end{array}$ & $\begin{array}{c}\text { Medium } \\
\text { heavy-duty truck }\end{array}$ & 1.36 & $\begin{array}{c}\text { Diesel } \\
(100 \%)\end{array}$ & 100 \\
\hline $\begin{array}{c}\text { Algae oil transported } \\
\text { to fuel production }\end{array}$ & Railway & 0.07 & $\begin{array}{c}\text { Residue oil } \\
(100 \%)\end{array}$ & 500 \\
\hline $\begin{array}{c}\text { Fuel transported } \\
\text { to terminal }\end{array}$ & Railway & 0.07 & $\begin{array}{c}\text { Residue oil } \\
(100 \%)\end{array}$ & 1000 \\
\hline $\begin{array}{c}\text { Fuel distributed } \\
\text { to airport }\end{array}$ & $\begin{array}{c}\text { Heavy } \\
\text { heavy-duty truck }\end{array}$ & 0.68 & $\begin{array}{c}\text { Diesel } \\
(100 \%)\end{array}$ & 50 \\
\hline
\end{tabular}

3.8. Energy and GHG Emissions Results

\subsubsection{Energy Returns on Investment for Algae Oil}

As Figure 6 shows, the EROI of algae oil is $\sim 2.0$ when only direct energy is accounted for. This is towards the pessimistic end of the range of 0.13 to 7.0 from the literature review in the NRC report [29].

Figure 6. Energy flows from algae cultivation to oil production with recycle process.

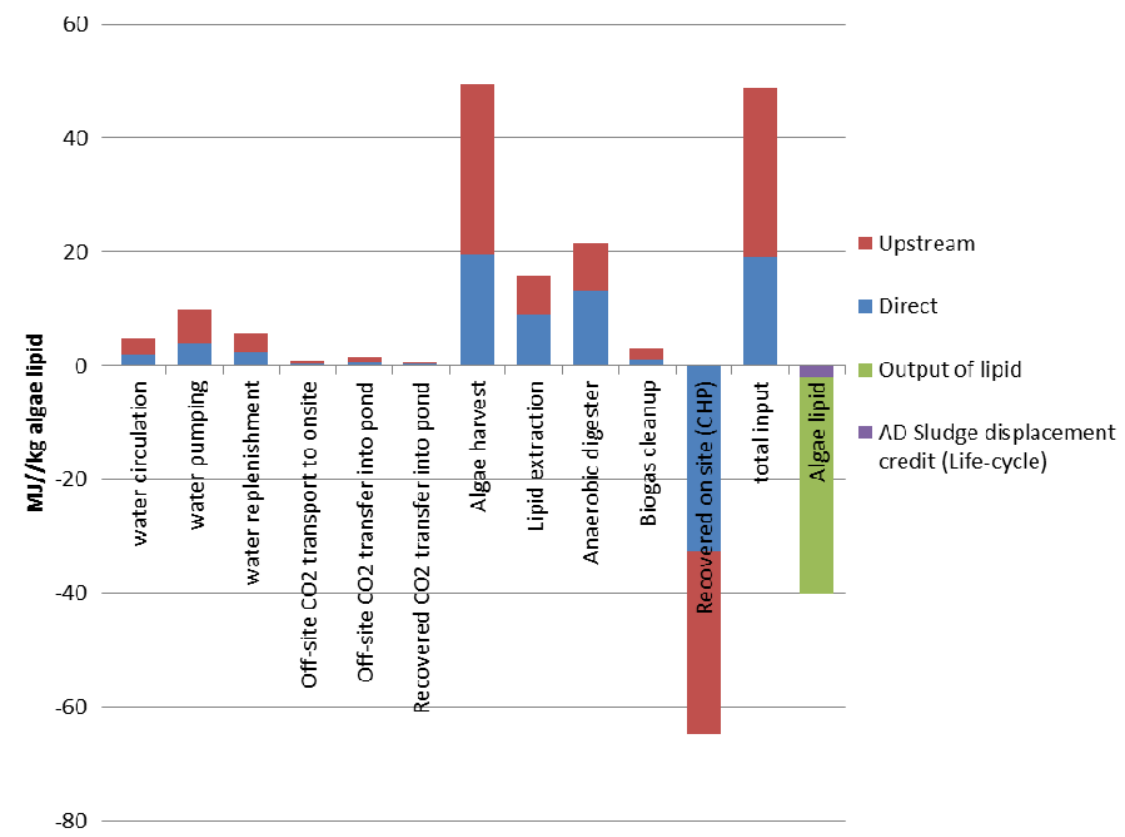


However, the EROI is only $\sim 0.80$ when the upstream energy is also accounted for. This figure is less than 1, meaning that the energy needed to produce the algae oil is greater than the energy contained in the algae oil and co-products.

\subsubsection{Life-Cycle Results for Algae Oil-Based Jet Fuel}

Our analyses showed that this hypothetical BJF pathway can increase total fossil energy use and GHG emission by $39 \%$ and $70 \%$, respectively, while reducing petroleum consumption by $84 \%$, compared with the CJF pathway (see Table 7).

Table 7. Life-cycle fossil energy use and GHG emissions for BJF and CJF.

\begin{tabular}{ccccc}
\hline Item & Unit & per MJ BJF & per MJ CJF & Ratio of BJF to CJF \\
\hline Life-cycle fossil Energy & $\mathrm{MJ} / \mathrm{MJ}$ & 1.76 & 1.26 & 1.39 \\
Of which, Coal & $\mathrm{MJ} / \mathrm{MJ}$ & 1.48 & 0.07 & 20.07 \\
Natural gas & $\mathrm{MJ} / \mathrm{MJ}$ & 0.10 & 0.06 & 1.73 \\
Petroleum & $\mathrm{MJ} / \mathrm{MJ}$ & 0.18 & 1.13 & 0.16 \\
Life-cycle GHG & $\mathrm{gCO}_{2, \mathrm{e}} / \mathrm{MJ}$ & 159 & 93 & 1.70 \\
\hline
\end{tabular}

Quantitative analyses in Figure 7 also show that the algae dewatering stage has the largest contribution $(31.7 \%)$ to total fossil energy use, due to the large amount of onsite heat and power demand.

Figure 7. Distribution of fossil energy use during various stages of the algae jet fuel pathway in China (with both the CHP energy output credit and AD sludge fertilizer credit considered).

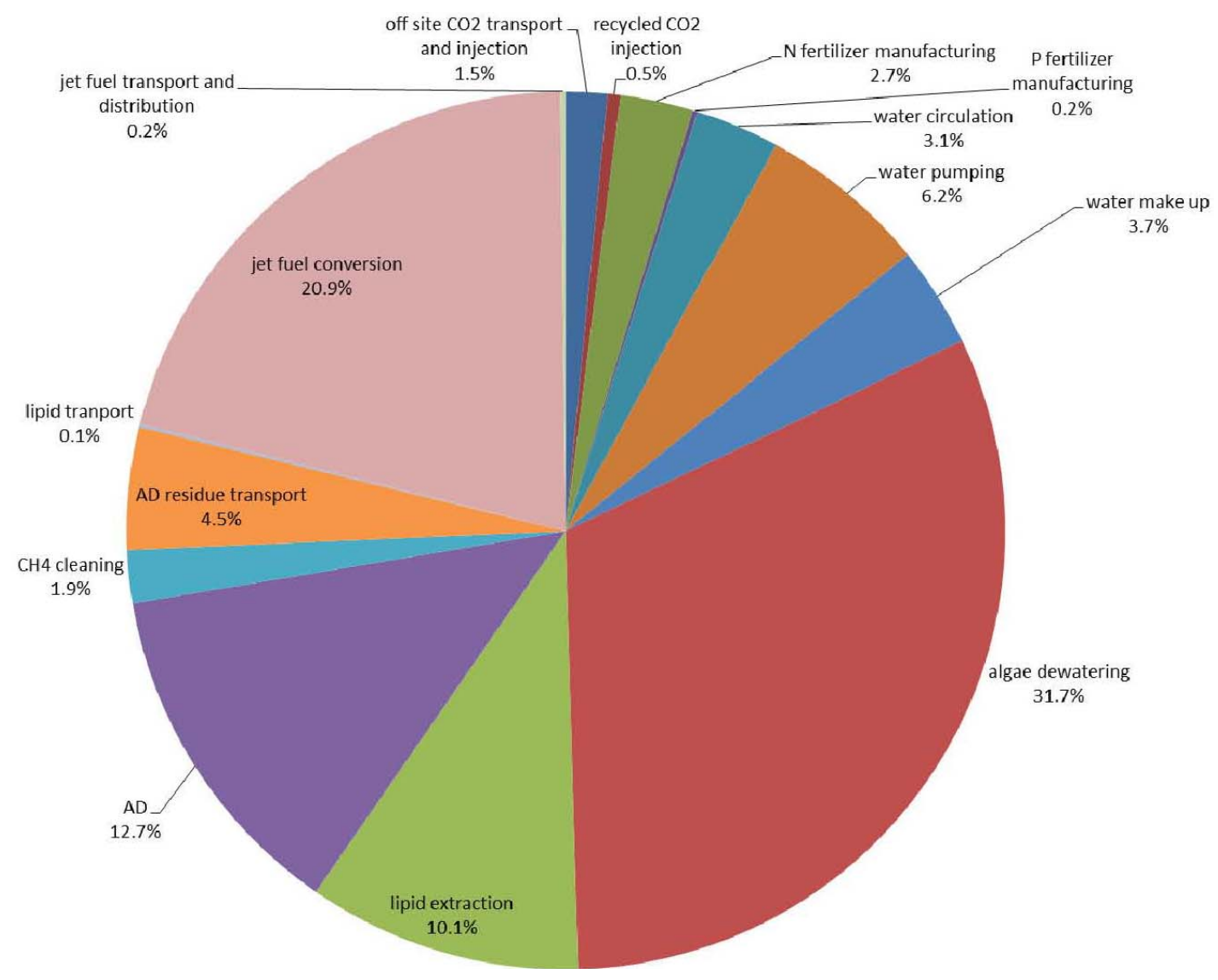


Jet fuel production stage takes the second position (21.0\%), due to heat and power demand and chemical use. The third largest contribution (17.9\%) is from the algae growth stage, which mainly involved fertilizer manufacturing, $\mathrm{CO}_{2}$ transport and injection, water pumping, circulation and freshwater making-up, and grid electricity consumption. The oil extraction stage also consumes about $10.1 \%$ of total fossil energy use in this pathway. Transport of both the oil and fuel has a very small contribution $(0.1 \%-0.2 \%)$ to the total fossil energy use. To achieve the CHP energy output credit and AD sludge fertilizer credit (about $60 \%$ and $3 \%$ of total fossil energy use in this pathway, respectively), penalties of fossil energy use in $\mathrm{AD}$, biogas cleaning and $\mathrm{AD}$ residue transport are also significant (12.7\%, 1.9 and $4.5 \%$ of total fossil energy use, respectively).

As shown in Figure 8, even with the GHG credits resulted from the CHP heat and electricity generation and the fertilizer production from AD sludge, the life-cycle GHG emissions remained high. This is due to the massive emissions from the algae growth and harvesting, oil extraction and jet fuel conversion stages as well as energy consumption and $\mathrm{CH}_{4}$ leakage during $\mathrm{AD}$ stage. About half of the life-cycle emissions (95.3 $\mathrm{g} \mathrm{CO}_{2, \mathrm{e}}$ per $\mathrm{MJ}$ ) is from the algae harvesting stage. Algae cultivation, oil extraction and jet fuel conversion stages are the other large contributing stages: 54.2, 31.2 and $35.1 \mathrm{~g}$ $\mathrm{CO}_{2, \mathrm{e}}$ per $\mathrm{MJ}$, respectively. Both the oil and the fuel transport stages have very small emissions, which are 0.2 and $0.3 \mathrm{~g} \mathrm{CO}_{2, \mathrm{e}}$ per $\mathrm{MJ}$, respectively.

Figure 8. Life-cycle GHG emissions for all stages in the algae jet fuel pathway in China (the $\mathrm{CO}_{2}$ emission from fuel combustion is offset by the intake for algae cultivation).

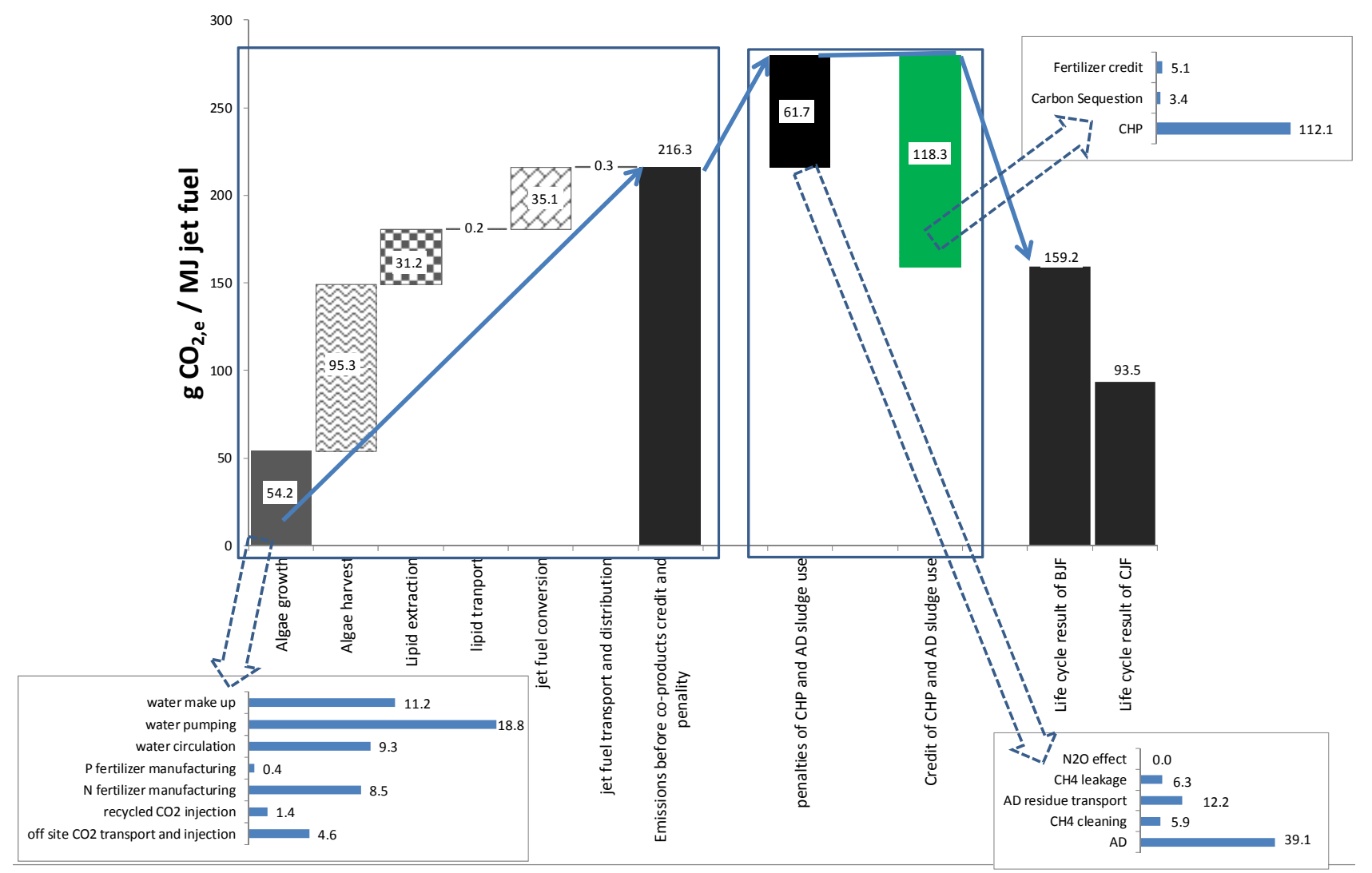

When looking into the algae growth stage, water movement related activities (water pumping, circulation and freshwater making-up) contribute half of the emissions, $\sim 39 \mathrm{~g} \mathrm{CO}_{2, \mathrm{e}}$ per $\mathrm{MJ}$, followed 
by fertilizer manufacturing related emissions of $8.9 \mathrm{~g} \mathrm{CO}_{2, \mathrm{e}}$ per $\mathrm{MJ} \mathrm{CO}_{2}$ transport and injection related emissions are only about $6 \mathrm{~g} \mathrm{CO}_{2, \mathrm{e}}$ per MJ.

The GHG emissions of algae BJF are $\sim 216.3 \mathrm{~g} \mathrm{CO}_{2, \mathrm{e}}$ per MJ when the credits and the penalties of CHP and AD sludge are not considered. The energy generated by the CHP system onsite results in a credit of $\sim 118.3 \mathrm{~g} \mathrm{CO}_{2, \mathrm{e}}$ per MJ when this system supply all of the heat and some of electricity demand for algae cultivation and oil extraction.

The displaced fertilizer credit (5.1 $\mathrm{g} \mathrm{CO}_{2, \mathrm{e}}$ per $\mathrm{MJ}$ ) originates from the $\mathrm{AD}$ sludge serving as nitrogen fertilizer to avoid chemical fertilizer production. There is also a credit $\left(3.4 \mathrm{~g} \mathrm{CO}_{2, \mathrm{e}}\right.$ per $\left.\mathrm{MJ}\right)$ from sequestration of carbon in the digestate solids.

The AD stage requires heat and power to produce biogas for use in the CHP after clean-up. The emissions are 39.1 and $5.9 \mathrm{~g} \mathrm{CO}_{2, \mathrm{e}}$ per $\mathrm{MJ}$ for the $\mathrm{AD}$ stage and biogas clean-up process, respectively. The emissions from transporting the wet digestate solids contributed $12.2 \mathrm{~g} \mathrm{CO}_{2, \mathrm{e}}$ per MJ. The fugitive $\mathrm{CH}_{4}$ emissions contribute $6.2 \mathrm{~g} \mathrm{CO}_{2, \mathrm{e}}$ per $\mathrm{MJ}$, due to subsequent handling of the digestate and biogas clean-up for the CHP. In this study, the direct $\mathrm{N}_{2} \mathrm{O}$ emissions due to $\mathrm{AD}$ sludge as fertilizer are not considered as the replaced chemical nitrogen fertilizers are expected to have the same emissions.

\subsection{Sensitivity Analysis}

A sensitivity analysis is performed to examine the effects of some key parameters on the life-cycle results. The details of the low-emission, high-emission and alternative cases are shown in Table 8 .

Table 8. Details of the low-emission, high-emission and alternative cases in this study.

\begin{tabular}{|c|c|c|c|c|}
\hline \multirow{2}{*}{ Parameter } & \multirow{2}{*}{ Unit } & \multicolumn{3}{|c|}{ Cases } \\
\hline & & Baseline case & Low case & High case \\
\hline Lipid content & $\mathrm{wt} \%$ & 25 & 50 & 1.25 \\
\hline Fresh water energy use & - & China current situation & Not counted in & $\begin{array}{c}\text { Similar to US } \\
\text { situation in [34] }\end{array}$ \\
\hline $\mathrm{CO}_{2}$ acquire energy use & - & Flue gas (20 vol\%) & Not counted in & $\begin{array}{c}\text { As pure } \mathrm{CO}_{2} \text { : } \\
140 \mathrm{kWh} / \mathrm{t}[54]\end{array}$ \\
\hline Algae productivity & $\mathrm{g} / \mathrm{m}^{2} /$ day & 2.5 & 5 & 1.25 \\
\hline Energy use for algae harvest & $\mathrm{kWh}$ per kg algae & About 1.2 & $\begin{array}{l}\text { About half } \\
\text { that in base case }\end{array}$ & $\begin{array}{l}\text { About } 10 \text { time that } \\
\text { in base case }\end{array}$ \\
\hline Energy use for lipid extraction & per kg lipid & $\begin{array}{c}6 \mathrm{MJ} \text { of heat and } \\
0.5 \mathrm{kWh} \text { of electricity }\end{array}$ & $\begin{array}{c}2 \mathrm{MJ} \text { of heat and } \\
0.1 \mathrm{kWh} \text { of electricity }\end{array}$ & $\begin{array}{c}12 \mathrm{MJ} \text { of heat and } \\
1.0 \mathrm{kWh} \text { of electricity }\end{array}$ \\
\hline $\mathrm{CH}_{4}$ yield & L/g-TS & 0.3 & 0.4 & 0.2 \\
\hline CHP electrical efficiency & $\%$ & 33 & 38 & 28 \\
\hline $\begin{array}{c}\text { Fraction of } \mathrm{N} \text { recovered to } \\
\text { culture }\end{array}$ & $\%$ & 75 & 65 & 85 \\
\hline- & - & Baseline case & Alterna & ive case \\
\hline Water pumping to/from pond & $\mathrm{kWh}$ per kg algae & $\begin{array}{c}195 \\
\text { (calculated by authors) }\end{array}$ & 1450(situa & on in [34]) \\
\hline Recovered energy by CHP & - & Yes & & \\
\hline $\begin{array}{c}\text { Embodied energy in pond } \\
\text { construction materials }\end{array}$ & - & No & $\begin{array}{r}\text { Yes. Energy embodic } \\
30 \% \text { that of biom }\end{array}$ & $\begin{array}{l}\text { in materials is about } \\
\text { iss produced [34]. }\end{array}$ \\
\hline
\end{tabular}


As Figure 9 shows, energy use for algae harvesting, energy use for water pumping and the lipid content are the three parameters with the highest impacts on life-cycle results.

Figure 9. Sensitivity Analysis for algae baseline case: (a) Life cycle fossil energy use and (b) Lifecycle GHG emissions.

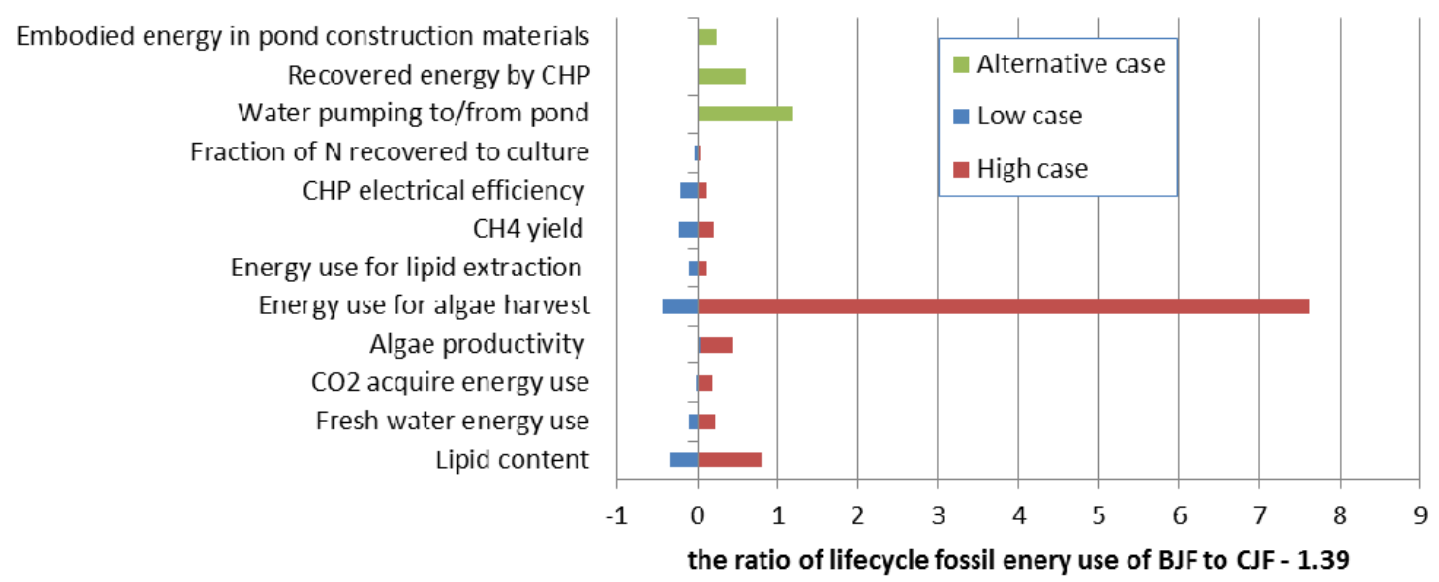

(a)

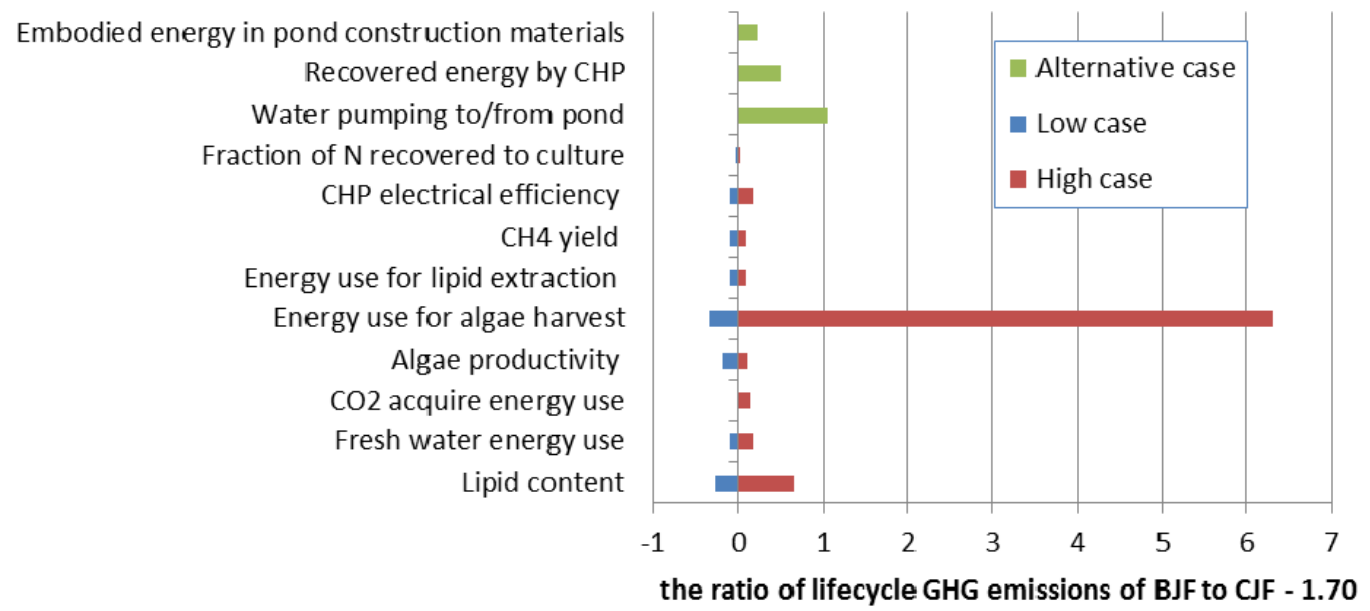

(b)

\subsection{Better Scenario Discussion}

The baseline scenario is modified with some key changes to improve the BJF pathway significantly, in order to achieve better energy and GHG performance of substituting CJF on a large scale.

A set of changes are assumed in a better scenario:

- It is obvious that the overall GHG emissions of this pathway can be greatly improved if the electricity and heat generation can be sourced from low-carbon fuels. Some potential improvements in the life cycle of algae-based fuel pathway are also assumed to be achieved in this future case. For example, more renewable electricity and cleaner power will be available in the future to change the coal-dominant power system in China currently;

- Because energy consumption during algae harvesting has a significant impact on the final result, it is also assumed that great efforts will be made to decrease the energy-intensity of algae 
harvesting to half that of the current level. This parameter in the future case will be reduced to only $10 \%$ of the assumed value in the baseline scenario;

- In addition, biogas yield from the LEA flow into the digester can be increased and thereby improve the LCA results further. This parameter in the future case will be increased by $33 \%$ from the assumed level in the baseline scenario;

- Based on the fact that the contributions of the stirring, pumping, water replenishment, algae dewatering, and even algae oil extraction to the overall GHG emissions (per unit jet fuel product) depend on the lipid content of the algae. The lipid content is assumed be increased from $25 \%$ to $50 \%$, to substantially reduce emissions for this pathway.

The final results of this scenario suggest $\sim 50 \%$ and $60 \%$ reductions in GHG emissions and fossil energy use, respectively; will be achieved as shown Figure 10. The two largest contributors to the reduction are the low-carbon electricity system and lower energy use for algae harvesting, both accounting for $\sim 40 \%$ of the reduction. The other two parameters each contributed $10 \%$ of the reduction.

Figure 10. Life cycle analysis results for BJF in better case: (a) Life-cycle fossil energy use and (b) Life-cycle GHG emissions.

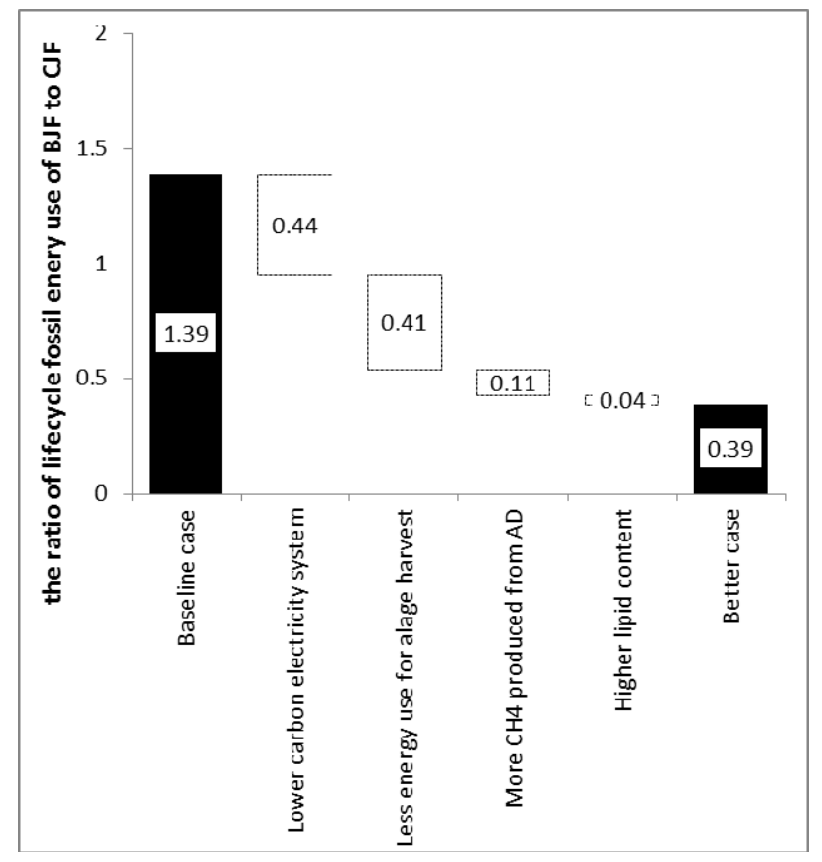

(a)

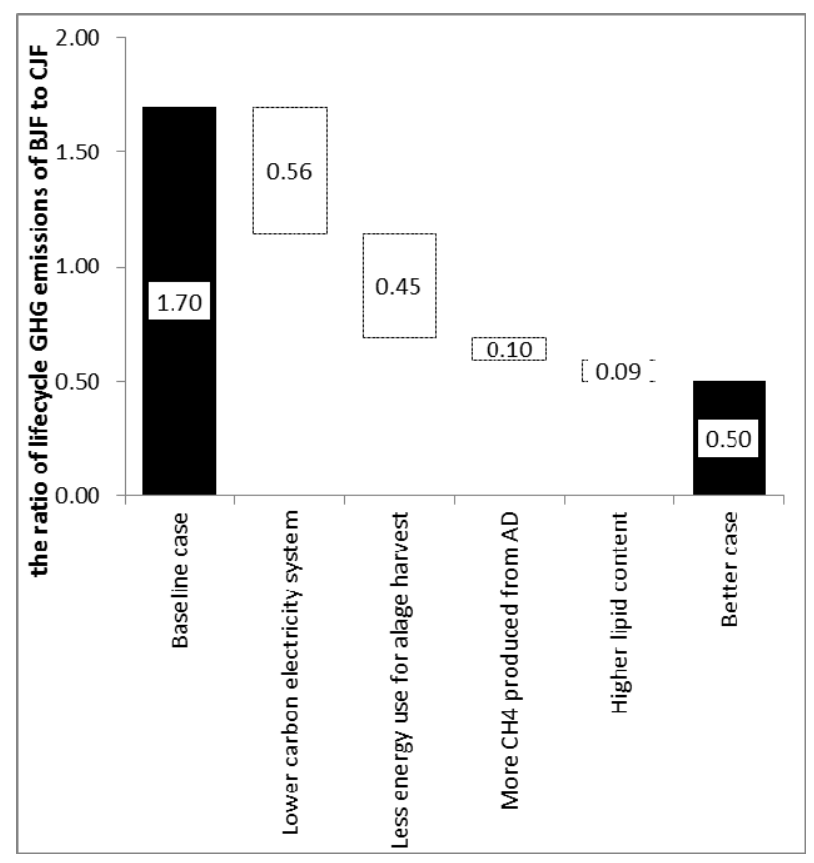

(b)

\subsection{Comparative Study}

Table 9 compares our LCA results with those from other studies. It can be seen that this study has relatively pessimistic results. For example, the ratio of life-cycle GHG emissions for BJF to $\mathrm{CJF}$ is 1.66 in the baseline case, worse than the mean value (1.44) from a literature review by Hantler et al. [55].

The following reasons explain the differences between this and other studies: (1) China's coal-dominant energy mix; (2) onsite monitoring of China's nitrogen fertilizer issues including 
feedstock source, transportation modes, and process energy consumption; and (3) comprehension of the $\mathrm{CO}_{2}$ and $\mathrm{CH}_{4}$ emissions associated with China's coal mining, crude oil and $\mathrm{NG}$ exploration stages.

The comparison of our study to the recent work of Vasudevan et al. [41] suggests that algae biofuels can yield GHG reductions relative to fossil fuels with the use of appropriate technology options and potential exists even for large reductions (>50\%) in GHG.

Table 9. Comparisons of results from different LCA studies on open-pond based algal BJF pathways.

\begin{tabular}{|c|c|c|c|c|c|}
\hline Source & $\begin{array}{l}\text { Location of } \\
\text { the study }\end{array}$ & $\begin{array}{c}\text { EROI } \\
\text { (direct) for } \\
\text { algae oil }\end{array}$ & $\begin{array}{c}\text { EROI } \\
\text { (Life-cycle) } \\
\text { for algae oil }\end{array}$ & $\begin{array}{l}\text { The ratio of lifecycle } \\
\text { fossil energy use for } \\
\text { algae-based jet fuel } \\
\text { to CJF }\end{array}$ & $\begin{array}{l}\text { The ratio of lifecycle } \\
\text { GHG emissions for } \\
\text { algae-based jet fuel to } \\
\text { CJF }\end{array}$ \\
\hline This study & China & $\begin{array}{l}\text { base case: } \\
2.0\end{array}$ & $\begin{array}{l}\text { base case: } \\
\quad 0.82\end{array}$ & $\begin{array}{l}\text { base case: } 1.36 \text { with } \\
\text { a range from } 1.01 \text { to } 7.68 \text {; } \\
\text { Better case: } 0.39\end{array}$ & $\begin{array}{c}\text { Base case: } 1.66 \text { with a } \\
\text { range from } 1.23 \text { to } \\
9.67 ; \\
\text { Better case: } 0.50\end{array}$ \\
\hline $\begin{array}{c}\text { Lardon et al. } \\
2009[24]\end{array}$ & Mediterranean & - & - & $\begin{array}{c}1.0 \text { (biodiesel to } \\
\text { Petroleum diesel) }\end{array}$ & $\begin{array}{l}1.1 \text { (biodiesel to } \\
\text { Petroleum diesel) }\end{array}$ \\
\hline $\begin{array}{c}\text { Clarens et al. } \\
2010[25]\end{array}$ & $\begin{array}{c}\text { Virginia, Iowa, } \\
\text { California in } \\
\text { USA }\end{array}$ & - & - & $\begin{array}{c}1.1 \text { (biodiesel to } \\
\text { Petroleum diesel) }\end{array}$ & $\begin{array}{l}0.61 \text { (biodiesel to } \\
\text { Petroleum diesel) }\end{array}$ \\
\hline $\begin{array}{c}\text { Jorquera et al. } \\
2010[56]\end{array}$ & $\begin{array}{l}\text { Unspecified } \\
\text { location }\end{array}$ & - & - & $\begin{array}{l}2.8 \text { (biodiesel to } \\
\text { Petroleum diesel) }\end{array}$ & - \\
\hline $\begin{array}{l}\text { Sander and } \\
\text { Murthy, } \\
2010[57]\end{array}$ & $\begin{array}{c}\text { U.S. } \\
\text { nationwide } \\
\text { data, } \\
\text { Unspecified } \\
\text { location }\end{array}$ & - & - & $\begin{array}{c}0.2 \text { (biodiesel to } \\
\text { Petroleum diesel) }\end{array}$ & $\begin{array}{l}0.50 \text { (biodiesel to } \\
\text { Petroleum diesel) }\end{array}$ \\
\hline $\begin{array}{c}\text { Stephenson et al. } \\
2010[58]\end{array}$ & $\begin{array}{c}\text { United } \\
\text { Kingdom }\end{array}$ & - & - & $\begin{array}{c}0.3 \text { (biodiesel to } \\
\text { Petroleum diesel) }\end{array}$ & $\begin{array}{l}0.64 \text { (biodiesel to } \\
\text { Petroleum diesel) }\end{array}$ \\
\hline $\begin{array}{c}\text { Campbell et al. } \\
2011[26]\end{array}$ & $\begin{array}{l}\text { Coastal } \\
\text { Australia }\end{array}$ & - & - & $\begin{array}{l}1.05 \text { (biodiesel to } \\
\text { Petroleum diesel) }\end{array}$ & $\begin{array}{l}0.56 \text { (biodiesel to } \\
\text { Petroleum diesel) }\end{array}$ \\
\hline $\begin{array}{l}\text { Liu et al. } \\
2011[59]\end{array}$ & - & - & $\begin{array}{c}1.6 \sim 4.0 \\
\text { (biodiesel) }\end{array}$ & - & - \\
\hline ANL [28] & USA & - & - & $\begin{array}{c}0.45 \text { (biodiesel to low } \\
\text { sulfur diesel) }\end{array}$ & $\begin{array}{l}0.55 \text { (biodiesel to } \\
\text { low sulfur diesel) }\end{array}$ \\
\hline $\begin{array}{l}\text { Handler et al. } \\
2012[55]\end{array}$ & $\begin{array}{l}\text { Unspecified } \\
\text { location }\end{array}$ & - & $0.1 \sim 2.3$ & - & $\begin{array}{c}\text { Three cases: } 0.61,1.44 \text {, } \\
5.38\end{array}$ \\
\hline $\begin{array}{c}\text { Stratton et al. } \\
2010[32]\end{array}$ & - & - & - & - & $\begin{array}{l}0.6 \text { with a range } \\
\text { from } 0.2 \text { to } 2.3\end{array}$ \\
\hline $\begin{array}{c}\text { Vasudevan et al. } \\
\text { (2012) [41] }\end{array}$ & - & - & - & \multicolumn{2}{|c|}{$\begin{array}{c}\text { (biodiesel to Petroleum diesel) } \\
\text { wet extraction: about } 0.5 ; \\
\text { Dry extraction: about } 3.00 \text {. }\end{array}$} \\
\hline
\end{tabular}




\section{Concluding Remarks}

Our life-cycle study suggests that compared with the traditional petrochemical pathway, the algae jet fuel pathway will increase overall fossil energy use and GHG emission by 39\% and 70\%, respectively, while decreasing petroleum consumption by $84 \%$. Energy conservation and emission reduction might be achieved for this new pathway by two approaches: wider adoption of low-carbon process fuels and optimization of algae cultivation and harvesting, and lipid extraction processes. Several barriers to the commercialization of this new biofuel pathway include algae strain selection and engineering system:

- Algae strain selection is one of the key bottlenecks for high lipid content algae cultivation in an open and wide system. Moreover, some strains should be selected to maximize the final algae lipid productivity based on the trade-off between algae biomass productivity and lipid content;

- Innovative design and technology integration should be introduced into this new pathway to decrease energy use and costs as some traditional processes (e.g., centrifugation and drying) are very energy-intensive.

For illustration purposes the size of the algae farm in this study is set at 100 ha. A much larger land area is required in practical operations. For example, about 100 farms with a size of 100 ha are needed to supply $50 \%$ of the energy use for a regular airport in China.

Resource requirements are very significant if this pathway is developed on a large scale. If $50 \%$ of total jet fuel consumption in 2012 is to be supplied by this pathway, $1.5 \%$ of total croplands and $10 \%$ of total water withdraw for crops in China will be needed. As for nutrients, the demand for $\mathrm{N}$ and $\mathrm{P}$ will be 1.2 and 0.5 million tons, respectively. This will also have a notable impact $(2 \%-3 \%)$ on the Chinese fertilizer market. Given the long-term phosphorous scarcity with global food security implications [60,61], limitations of phosphorous supply for algae farming cannot be overlooked even though China has a substantial advantage over many other countries due to its phosphorous resources. Whether the water make-up by freshwater can be replaced by saline, brackish or waste water that contain abundant nutrients for algae growth, is another important area for research. In addition, $\mathrm{CO}_{2}$ source availability should be assessed in details with regard to transportation mode and distance, even though the $\mathrm{CO}_{2}$-rich flue gas of power plants and chemical factories is abundant.

\section{Acknowledgments}

The project is co-supported by the China National Natural Science Foundation (Grant No. 71041028, 71103109), and the CAERC program (Tsinghua/GM/SAIC-China). The authors would like to thank the reviewers for their generous help.

\section{Conflicts of Interest}

The authors declare no conflict of interest. 


\section{References}

1. International Energy Agency (IEA). World Energy Outlook 2011; IEA: Paris, France, 2011.

2. National Bureau of Statistics of China. China Statistics 2012; China Statistics Press: Beijing, China, 2012.

3. British Petroleum (BP). BP Statistical Review of World Energy 2012. Available online: http://bp.com/statisticalreview (accessed on 26 November 2012).

4. Wang, Q.Y. China Energy Data 2011 [in Chinese]; China Automotive Energy Research Center (CAERC): Beijing, China, 2011.

5. China Energy Research Society. China Energy Development Report 2013 [in Chinese]; China Electric Power Press: Beijing, China, 2013.

6. China Automotive Energy Research Center (CAERC). China Automotive Energy Outlook 2012 [in Chinese]; Scientific Press: Beijing, China, 2012.

7. Yan, X.; Crookes, R.J. Reduction potentials of energy demand and GHG emissions in China's road transport sector. Energy Policy 2009, 37, 658-668.

8. Yan, X.; Crookes, R.J. Energy demand and emissions from road transportation vehicles in China. Prog. Energy Combust. Sci. 2010, 36, 651-676.

9. Delluchi, M.A. A Lifecycle Emissions Model (LEM); Institute of Transportation Studies: Davis, CA, USA, 2003.

10. Wang, M.Q.; Santini, D. Magnitude and value of electric vehicles emissions reduction for six driving cycles in four US cities with varying air quality problems. Transp. Res. Rec. 1993, $1416,33-42$.

11. Delluchi, M.A. A Revised Model of Emissions of GHG from the Use of Transportation Fuels and Electricity; Institute of Transportation Studies: Davis, CA, USA, 1997.

12. Wang, M.Q. Development and Use of GREET 1.6 Fuel-Cycle Model for Transportation Fuels and Vehicle Technologies; Center for Transportation Research, Argonne National Laboratory: Argonne, IL, USA, 2001.

13. Wang, M.; Wu, Y.; Elgowainy, A. Operating Manual for GREET Version 1.7. Available online: http://greet.anl.gov/publications.html (accessed on 26 November 2012).

14. Wang, M.Q.; Weber, T. Well-to-Wheels Energy Use and GHG Emissions of Advanced Fuel/Vehicles System-North American Analysis; Center for Transportation Research, Argonne National Laboratory: Argonne, IL, USA, 2001.

15. China Automotive Technology and Research Center (CATARC) and General Motor. Well-to-Wheels Analysis of Energy Consumption and GHG Emissions of Multi Vehicle Fuel in Future China; CATARC: Beijing, China, 2007.

16. Nguyen, T.L.T.; Gheewala, S.H.; Garivait, S. Full chain energy analysis of fuel EtOH from cane molasses in Thailand. Appl. Energy 2008, 85, 722-734.

17. Yan, X.; Boies, A.M. Quantifying the uncertainties in life cycle greenhouse gas emissions for UK wheat ethanol. Environ. Res. Lett. 2013, 8, 015024:1-015024:12.

18. Yan, X.; Tan, D.K.Y.; Inderwildi, O.R.; Smith, J.A.C.; King, D.A. Life cycle energy and greenhouse gas analysis for agave-derived bioethanol. Energy Environ. Sci. 2011, 4, 3110-3121. 
19. Shirvani, T.; Yan, X.; Inderwildi, O.R.; Edwards, P.; King, D.A. Life cycle energy and greenhouse gas analysis for algae-derived biodiesel. Energy Environ. Sci. 2011, 4, 3773-3778.

20. Allen, D.T.; Allport, C.; Atkins, K. Framework and Guidance for Estimating Greenhouse Gas Footprints of Aviation Fuels; Air Force Research Laboratory: Wright-Patterson, OH, USA, 2009.

21. Lardon, L.; Helias, A.; Sialve, B.; Stayer, J.; Bernard, O. Life-cycle assessment of biodiesel production from microalgae. Environ. Sci. Technol. 2009, 43, 6475-6481.

22. Clarens, A.F.; Resurreccion, E.P.; White, M.A.; Colosi, L.M. Environmental life cycle comparison of algae to other bioenergy feedstocks. Environ. Sci. Technol. 2010, 44, 1813-1819.

23. Campbell, P.K.; Beer, T.; Batten, D. Life cycle assessment of biodiesel production from microalgae in ponds. Bioresour. Technol. 2011, 102, 50-56.

24. Collet, P.; Hélias, A.; Lardon, L.; Ras, M.; Goy, R.A.; Steyer, J.P. Life-cycle assessment of microalgae culture coupled to biogas production. Bioresour. Technol. 2011, 102, 207-214.

25. Frank, E.D.; Han, J.; Wang, M.Q. Life-Cycle Analysis of Algal Lipid Fuels with the GREET Model; Energy Systems Division, Argonne National Laboratory: Argonne, IL, USA, 2011.

26. National Research Council of the National Academies (NRC). Sustainable Development of Algal Biofuels in the United States; The National Academies Press: Washington, DC, USA, 2012.

27. Yan, X.; Crookes, R.J. Life cycle analysis of energy use and greenhouse gas emissions for road transportation fuels in China. Renew. Sustain. Energy Rev. 2009, 13, 2505-2514.

28. Hou, J.; Zhang, P.; Yuan, X.; Zheng, Y. Life cycle assessment of biodiesel from soybean, jatropha and microalgae in China conditions. Renew. Sustain. Energy Rev. 2011, 15, 5081-5091.

29. Stratton, R.W.; Wong, H.M.; Hileman, J.I. Life Cycle Greenhouse Gas Emissions from Alternative Jet Fuels; MIT Press: Cambridge, MA, USA, 2010.

30. Ou, X.; Zhang, X.; Chang, S. Energy consumption and GHG emissions of six biofuel pathways by LCA in (the) People's Republic of China. Appl. Energy 2009, 86, S197-S208.

31. Ou, X.; Chang, S.; Zhang, X. Alternative fuel buses currently in use in China: Life-cycle fossil energy use, GHG emissions and policy recommendations. Energy Policy 2010, 38, 406-418.

32. Li, X.; Ou, X.; Zhang, X. Life-cycle fossil energy consumption and greenhouse gas emission intensity of dominant secondary energy pathways of China in 2010. Energy 2013, 50, 15-23.

33. Murphy, C.F.; Allen, D.T. Energy-Water Nexus for Mass Cultivation of Algae. Environ. Sci. Technol. 2011, 45, 5861-5868.

34. UOP A Honeywell Company. Green Jet Fuel. Available online: http://www.uop.com/ processing-solutions/biofuels/green-jet-fuel/ (accessed on 26 November 2012).

35. Hu, X.; Li, Z.; Fu, X. Liquid Biofuels: From Fossil to Biomass [in Chinese]; Chemical Industry Press: Beijing, China, 2012.

36. China Automotive Energy Research Center (CAERC). Aviation Fuel Life Cycle Analysis in China; CAERC: Beijing, China, 2013.

37. Wang, M.; Lee, H.; Molburg, J. Allocation of energy use in petroleum refineries to petroleum products: Implications for life-cycle energy use and emission inventory of petroleum transportation fuels. Int. J. Life Cycle Assess. 2004, 9, 34-44.

38. Davis, R.; Aden, A.; Pienkos, P.T. Techno-economic analysis of autotrophic microalgae for fuel production. Appl. Energy 2011, 88, 3524-3531. 
39. Kadam, K.L. Environmental implications of power generation via coal-microalgae cofiring. Energy 2002, 27, 905-922.

40. Vasudevan, V.; Stratton, R.W.; Pearlson, M.N.; Jersey, G.R.; Beyene, A.G.; Weissman, J.C.; Rubino, M.; Hileman, J.I. Environmental performance of algal biofuel technology options. Environ. Sci. Technol. 2012, 46, 2451-2459.

41. Lundquist, T.J. Realistic Technology and Engineering Assessment of Algae Biofuel Production; Energy Biosciences Institute: Berkeley, CA, USA, 2010.

42. Harris, R.W. Process Design and Cost Estimating Algorithms for the Computer Assisted Procedure for Design and Evaluation of Wastewater Treatment Systems; U.S. Environmental Protection Agency: Washington, DC, USA, 1982.

43. Ren, G.; Guo, J. Chang in pan evaporation and influential factors over China: 1965-2000 [in Chinese]. J. Nat. Resour. 2006, 21, 31-44.

44. Hu, G.; Ou, X.; Zhang, Q.; Karplus, V.J. Analysis on energy-water nexus by Sankey diagram: The case of Beijing. Desalin. Water Treat. 2013, 51, 4183-4193.

45. Mohn, F.H. Experiences and Strategies in the Recovery of Biomass from Mass Cultures of Microalgae. In Algae Biomass; Elsevier: Oxford, UK, 1980; pp. 547-571.

46. Uduman, N.; Qi, Y.; Danquah, M.K.; Forde, G.M.; Hoadley, A. Dewatering of Microalgal Cultures: A Major Bottleneck to Algae-Based Fuels. J. Renew. Sustain. Energy 2010, 2, 012701:1-012701:15.

47. Benemann, J.R.; Oswald, W.J. Systems and Economic Analysis of Microalgae Ponds for Conversion of $\mathrm{CO}_{2}$ to Biomass; Pittsburgh Energy Technology Center: Pittsburgh, PA, USA, 1996.

48. Environmental Protection Agency (EPA). Emerging Technologies for Bio Solids Management; EPA: Washington, DC, USA, 2006.

49. Klein-Marcuschamer, D.; Turner, C.; Allen, M.; Gray, P.; Dietzgen, R.G.; Gresshoff, P.M.; Hankamer, B.; Heimann, K.; Scott, P.T.; Stephens, E.; et al. Technoeconomic analysis of renewable aviation fuel from microalgae, Pongamia pinnata, and sugarcane. Biofuels Bioprod. Biorefin. 2013, 7, 416-428.

50. Ras, M. Experimental study on a coupled process of production and anaerobic digestion of Chlorella vulgaris. Bioresour. Technol. 2011, 102, 200-206.

51. Petersson, A.; Wellinger, A. Biogas Upgrading Technologies: Developments and Innovations; IEA: Paris, France, 2009.

52. Flesch, T.K.; Raymond, L.; Desjardins, D.W. Fugitive $\mathrm{CH}_{4}$ Emissions from an Agricultural Biodigester. Biomass Bioenergy 2011, 9, 3927-3935.

53. Ou, X.; Zhang, X. Life-Cycle Analysis of Automotive Energy Pathways in China [in Chinese]; Tsinghua University Press: Beijing, China, 2011.

54. Jaramillo, P.; Samaras, C.; Wakeley, H.; Meisterling, K. Greenhouse gas implications of using coal for transportation: Life cycle assessment of coal-to-liquids, plug-in hybrids, and hydrogen pathways. Energy Policy 2009, 37, 2689-2695.

55. Handler, R.M.; Canter, C.E.; Kalnes, T.N.; Lupton, F.S.; Kholiqov, O.; Shonnard, D.R.; Blowers, P. Evaluation of environmental impacts from microalgae cultivation in open-air raceway ponds: Analysis of the prior literature and investigation of wide variance in predicted impacts. Algal Res. 2012, 1, 83-92. 
56. Jorquera, O.; Kiperstok, A.; Sales, E.A.; Embiruau, M.; Ghirardi, M.L. Comparative energy life-cycle analyses of microalgal biomass production in open ponds and photobioreactors. Bioresour. Technol. 2010, 101, 1406-1413.

57. Sander, K.; Murthy, G.S. Life cycle analysis of algae biodiesel. Int. J. Life Cycle Assess. 2010, 15, 704-714.

58. Stephenson, A.L.; Kazamia, E.; Dennis, J.S. Life-cycle assessment of potential algal biodiesel production in the United Kingdom: A comparison of raceways and air-lift tubular bioreactors. Energy Fuels 2010, 24, 4062-4077.

59. Liu, X.; Clarens, A.F.; Colosi, L.M. Algae biodiesel has potential despite inconclusive results to date. Bioresour. Technol. 2012, 104, 803-806.

60. Cordell, D.; Dragnet, J.-O.; White, S. The Story of phosphorus: Global food security and food for thought. Glob. Environ. Chang. 2009, 19, 292-305.

61. Vaccari, D.A.; Strigul, N. Extrapolating phosphorus production to estimate resource reserves. Chemosphere 2011, 84, 792-797.

(C) 2013 by the authors; licensee MDPI, Basel, Switzerland. This article is an open access article distributed under the terms and conditions of the Creative Commons Attribution license (http://creativecommons.org/licenses/by/3.0/). 